\title{
Equity Issues in Policymaking in Transition Economies
}

\author{
Grzegorz W. Kolodko \\ Professor, Warsaw School of Economics, Poland, and \\ Senior Visiting Fellow at the Development Economics \\ Research Group, World Bank
}

\author{
Prepared for \\ Conference on Economic Policy and Equity \\ June 8-9, 1998 \\ International Monetary Fund \\ Washington, D.C.
}

\section{Published in:}

Vito Tanzi, Ke-young Chu, and Sanjeev Gupta. (eds.), (1999). "Economic Policy and Equity", International Monetary Fund, Washington, DC, pp. 150-88. 


\title{
Equity Issues in Policymaking in Transition Economies
}

\author{
Grzegorz W. Kolodko*
}

Professor at Warsaw School of Economics, Poland, and

Senior Visiting Fellow at the Development Economics Research Group, World Bank 
*The author was the First Deputy Premier and Minister of Finance of Poland in 1994-97, and led his country into OECD membership in 1996. In 1997-98, he was Distinguished Sasakawa Chair for Development Policy at the United Nations University World Institute for Development Economics Research (UNU/WIDER), in Helsinki. He is currently an Advisor to the President of Poland. The views expressed in this paper are those of the author and do not necessarily represent those of the IMF or other institutions. 


\section{CONTENTS}

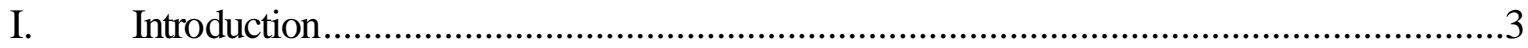

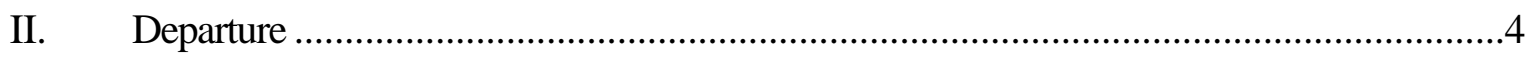

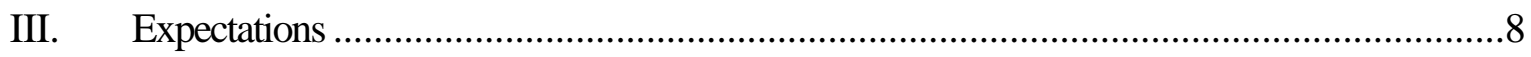

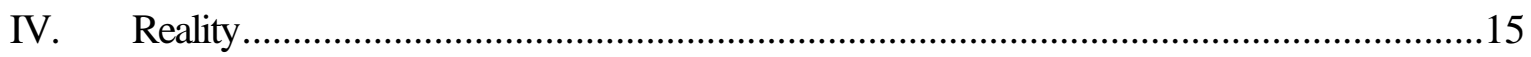

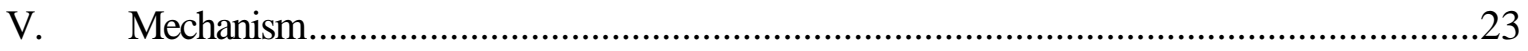

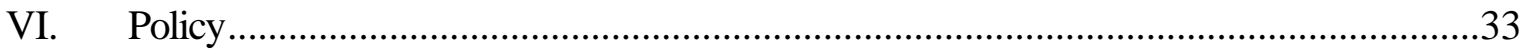

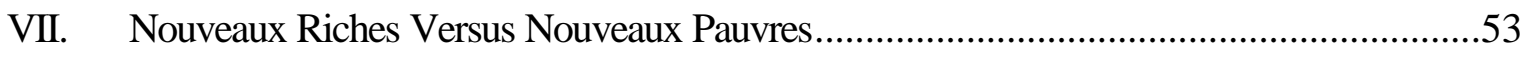

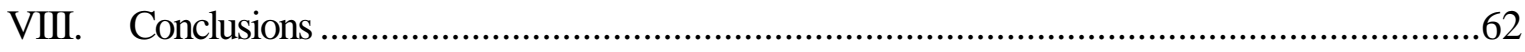

\section{Text Tables}

1. Income Inequality Indexes in Eastern and Western Europe, 1986-87 ..............................5

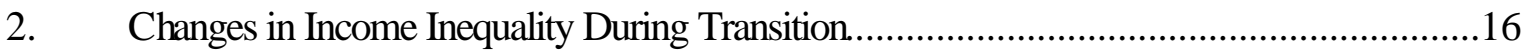

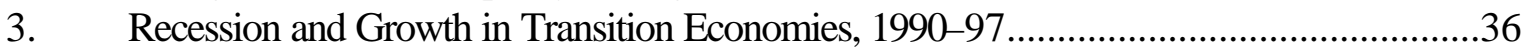

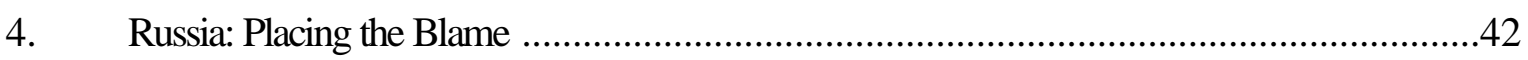

5. Increase in Poverty and GDP Decline During Transition, 1987-94 ..................................57

Figures

1. Changes of Gini Coefficient in Transition Economies, 1998/88-1993/94..........................18

2. Poland: Gini Coefficient During Implementation of Strategy for Poland............................43

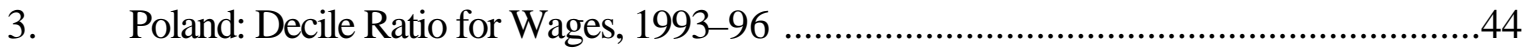

4. Selected Countries: Poverty Groups, 1987/88 and 1993/94 ......................................55

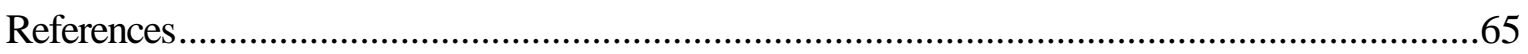




\section{INTRODUCTION}

The biggest challenge an economist can face is not answering a difficult theoretical question but introducing reforms and making the day-to-day policy decisions that will prove that theory works. However, often that theory does not work. The next challenge, then, is to modify the theory or to keep trying to change the reality to follow that theory.

In the real world, far from the ivory tower of academia and elegant models, political life is brutal. What matters is political power, not the logical arguments and statistical evidence. In a classroom or at a conference, it may be enough to be right and to be able to prove it in a scholarly way; policymakers, however, need a majority in the parliament and, more important, social and political support for reforms. Policymakers need to be wise and effective, but these attributes do not always go together.

Equity issues in policymaking are difficult to resolve because they are linked not only to economic matters but also to social constraints and political conflicts. What is fair and what is not, seems to be more a matter for ideological or philosophical dispute, not mathematical models. Equity is always a concern of policymaker, especially in transition economies' early years of systemic change and severe contraction.

This paper discusses first the characteristics of income distribution under the former centrally planned system, then the changes taking place during transition to a market economy. Expectations for income patterns and wealth distribution are examined as is the issue of increasing inequality. This paper then reviews the policy options and evaluates the transition's impact on inequity and inequality, and concludes that although inequality inevitably rises during transition, policymakers must link income distribution and growth to sustainable development. The recent successful implementation of Poland's transition strategy suggests that it is feasible.

\section{DEPARTURE}

Income distribution under the centrally planned system was more equal than during the transition period as well as compared with the market economies. However, among these economies of Central and Eastern Europe inequality varied. It is possible, however, to distinguish some patterns by examining these countries' Gini coefficients (reflecting here distribution of net disposable income). In the late 1980s, the Gini coefficient varied from a low of 20 (for the Slovak Republic), to 28 (for Uzbekistan), mostly being between 23 and 24 points. Compared with the advanced market economies, the countries of Eastern Europe - excluding the former Yugoslaviahad Gini coefficients of, on average, 6 percentage points less than Western European countries (see Table 1). 
If one would use the classification proposed (Atkinson, Rainwater, and Smeeding, 1995) for the OECD from the viewpoint of inequality, none of the former centrally planned economies would qualify as high income inequality (Gini coefficient of 33-35), or even 
Table 1. Income Inequality Indexes in Eastern and Western Europe, 1986-87

\begin{tabular}{|c|c|c|c|c|}
\hline \multirow{4}{*}{ Income } & \multicolumn{2}{|c|}{ Gross Earnings } & \multicolumn{2}{|c|}{ Net Disposable } \\
\hline & & & & \\
\hline & Gini & Decile & Gini & Decile \\
\hline & Coefficient & Ratio & Coefficient & Ratio \\
\hline Czechoslovakia & 19.7 & 2.5 & 19.9 & 2.4 \\
\hline Hungary & 22.1 & 2.6 & 20.9 & 2.6 \\
\hline Poland & 24.2 & 2.8 & 25.3 & 3.0 \\
\hline Soviet Union & 27.6 & 3.3 & 25.6 & 3.3 \\
\hline Great Britain & 26.7 & 3.2 & 29.7 & 3.9 \\
\hline United States 1/ & & & 31.7 & \\
\hline West Germany 2/ & & & 25.2 & \\
\hline Australia & & & 28.7 & \\
\hline
\end{tabular}

Sources: Atkinson and Micklewright (1992); and Milanovic (1998).

1/ 1987.

2/ 1981.

average income inequality (29-31). All of these economies would be either low income inequality (24-26) or very low income inequality (20-22). Hence, before transition, the dominant pattern of income distribution should be considered as relatively equal. If measured by the Gini coefficients in terms of distribution of disposable income, the situation was similar in Finland, Sweden, West Germany, the Netherlands, and Norway.

Let us examine income distribution and inequality in the former centrally planned economies compared to that of the market economies at that time. This comparison will help explain the qualitative changes that occurred later, during the transition. However, one should note two groups of systemic differences between centrally planned and free market economies, and their policy implications during the transition. The first difference is the primary nominal income distribution; the second, the income redistribution mechanism. 
Regarding primary income distribution first, in the socialist economies, the dominant state and collective ownership of the means of production minimized the role of capital gains, profits, rents, dividends. This type of individual income did play a marginal role but only in countries (Hungary, Poland, and Yugoslavia), with a significant private sector did it influence households' inc ome distribution. ${ }^{1}$ However, the interest was not significant due to weak banking sectors and lack of other financial intermediaries; wages and pensions accounted for most households disposable income.

Second, concerning the income redistribution mechanism the wage systems and policies were very centralized, and in only a few countries (again, especially in Hungary, Poland and Yugoslavia) did the market-oriented reforms allow for relatively greater wage diversification. In Poland in the 1970s, the highest-to-lowest-wage ratio could not exceed 6:1, although for about 90 percent of the labor force, the actual wages ratio was 3:1. Social and political pressure for egalitarian redistribution of income was indeed very strong. This pressure, together with the egalitarian ideology was the driving force behind more equal income distribution than elsewhere, and impacted heavily on labor allocation and productivity.

Third, the state pension system was directly linked to the wage system. Therefore, the proportions of pensions for the retired and social benefits for the disabled were similar to the proportions of salaries. Of course, on average, pensions were lower than wages, but their proportions were a consequence of a more or less egalitarian wage policy.

As for the redistribution of the primary nominal income under the socialist system, first, the extensive range of subsidies on basic goods and services was of great importance. In Poland in 1980 - the year of the largest working class protest ever held in a socialist country - the subsidies accounted for as much as 10 percent of the national income. However, their distribution, although mainly to the poor, did not make real income allocation, or in-kind consumption more fair. Subsidies were granted for goods and services with low income elasticity, mainly apartment rent and mass transportation. These subsidies targeted the lower-income groups (Cornia, 1996a), but also helped middle-income households because, for instance, the larger the apartment one had and the more often one traveled, the greater the subsidy.

\footnotetext{
${ }^{1}$ For instance, in Poland in 1989, about 20 percent of GDP was from the private sector, of which about one-third was nonagricultural.
} 
Second, unlike in the market economies, taxation did not play an important role. Direct taxes were of marginal significance in income dispersion-they accounted for no more than 2 percent of gross salaries and in the majority of cases there was no difference between gross and net income. For most of the population, gross remuneration was the same as net compensation, with all consequences and policy implications for transition to a new system.

Third, shortages were common to all these economies. Although shortages differed among countries — in goods, intensity, and timing — they influenced the final distribution of real disposable income in a major way (Kornai, 1980; Kolodko,1986; Nuti,1989). The "shortageflation" phenomenon - that is, vast shortages accompanied by an open, price inflation (Kolodko and McMahon, 1987)—-had a major effect on actual consumption. Income was often insufficient to acquire needed goods and services, so nominal demand could not be satisfied. Queuing, rationing schemes, parallel markets, forced substitution, involuntary savings, and corruption were common in the distribution system. True access to scarce goods and services sometimes had even greater significance than the nominal money income. Hence, it is impossible to evaluate the income dispersion based only on the data on money income dispersion. This legacy and such point of departure toward the new system have impacted heavily upon the expectations and changes in income distribution patterns in the postsocialist countries.

\section{EXPECTATIONS}

There is no doubt that one of the main causes of the postsocialist revolution in the Central and Eastern European countries stemmed from the peoples' conviction that income distribution was unfair and unequal, contrary to political claims and the system's ideological foundations. It is difficult to say whether the people were more concerned about the level of their income or the way it was distributed, however, it is likely that the latter played a greater role in sparking the transition. The desire for fair and equal income distribution was very strong, and social dissatisfaction and political tensions were rising due to the growing disparity in real income.

Of course, there were other factors that helped push these countries toward a market-oriented economy. The people played, in fact, three roles simultaneously: as producers, they were disappointed that some of their efforts were wasted by mismanagement, stagnating output, and the lack of ability to compete; as consumers, they were irritated by the growing inefficiencies of the distribution system and the time they had to spend for shopping; and as citizens, they were dissatisfied by their inability to influence economic, social, and political changes. Only the combination of these three motives was strong enough to ignite the push out from a centrally planned economy toward a market system. 
However, not only at the onset of the transition but still today, some do not want to move from relatively egalitarian socialism to less egalitarian capitalism. ${ }^{2}$ There is still considerable naïveté that the market regime will bring higher and more equitably distributed income.

Ongoing political debates and the exaggerated demonstration effect from industrialized countries have fueled unrealistic expectations. The excessive optimism among the new political class does not take into account these industrialized countries' histories. The common people are even more unrealistic. They have been told by the new elite that as soon as they get rid of the old system, the distribution of income (of course, higher) will be more favorable. The best example of this is the populist Solidarity movement in Poland.

\footnotetext{
${ }^{2}$ The results of recent elections in some transition countries (e.g. , in March 1998, in Armenia and Ukraine) support this observation.
} 
Hence, at the beginning of the transition, there was the widespread conviction that this process would quickly bring both higher income and more fair distribution of the fruits of a better-performing economy. As naïve as this attitude is, it is still present, even among some professionals and leading politicians familiar with the economic and social realities. Optimism increased when five of the transition countries began accession negotiations with the European Union in March 1998, leading some to believe that the development gap between the transition countries and those in Western Europe would be closed with 10 years or so. ${ }^{3}$ Unfortunately, it will take longer.

\footnotetext{
${ }^{3}$ These five countries (the Czech Republic, Estonia, Hungary, Poland, and Slovenia) have been EU associate members since 1994. Five other countries (Bulgaria, Latvia, Lithuania, Slovak Republic and Romania) are associated with EU, but have not yet been invited to begin accession negotiations.
} 
The gap is too large to close in one generation. ${ }^{4}$ Closing the institutional gap will take a long time, closing the development gap even longer. This can be accomplished only when the rate of growth in Eastern Europe is much faster than in Western Europe. Due to the severe collapse in output during the first eight years of the transition, the gap between these two parts of the continent has widened. To increase GDP by 300 ECU, a country with a GDP of 15,000 ECU, needs 2 percent growth, a country with 6,000 ECU needs 5 percent growth, and one with 3,000 ECU needs 10 percent.

Unrealistic expectations for quick transition results and world economic integration can be explained more by political, ideological and psychological factors than economic. However, these countries were relatively backward and did not expect such high costs of structural adjustment and recession, which caused additional increase in social and political tensions. Thus, one should not expect more than is feasible.

However, in the observed social process something different has occurred. On the one side, the strong component of ideological and political struggles raised expectations beyond anyone's capability to satisfy them in the foreseeable future. On the other side, the irrational temptations to get to a "better world" faster than feasible - enhanced by the spread of the demonstration effect and intentional, although ill-advised, postcommunist propaganda - have strengthened the social and political tensions that have stemmed from the inability to meet unrealistic hopes.

Political leaders assumed that price liberalization and the elimination of shortages would lead to more equal income distribution. In some countries, such as the Czech Republic and Russia, these leaders thought that privatization through free asset distribution would improve income distribution. Vast circles of professionals and politicians believed that the reforms of the transfer system, especially of pensions, should not raise income inequality, but rather the opposite. Nevertheless, for a number of reasons, this has not been the case.

Short-term results did contribute to more equal income distribution, for instance, price liberalization improved access to goods that had been in short supply. Politicians and the policy

\footnotetext{
${ }^{4}$ According to EU Commission and Eurostat estimates, the GDP per capita on a PPP basis is 3,900 ECU in Estonia, 5,300 in Poland, 6,300 in Hungary, 9,100 in the Czech Republic, and 10,100 in Slovenia. Thus, the average income is between 35 percent and 65 percent of the average income in Western Europe. This is indeed a very large gap.
} 
makers took advantage of this to improve their constituents' standards of living. Soon thereafter, however, other transition events, such as the severe contraction of real salaries and the rapid increase in unemployment, worsened income inequality and increased the number of poor.

Thus, the policy was, in a sense, to walk from one point-of-no-return to the next. The clearest example of this is still seen in Russia, where the gap between expectations and achievements has grown since the transition began. In Poland, this gap existed in the early stage of transition only, because the accompanying costs were too high; thereafter, policy design was more realistic (Poznanski, 1996, Kolodko and Nuti, 1997).

In the early 1990s in Poland, there was indeed shock, but not much therapy. It was assumed that output (in terms of real GDP) would contract by as little as 3.1 percent; indeed, it collapsed by about 12 percent in 1990 and by an additional 7.2 percent in 1991. During the same period, industrial output shrank by 40 percent (in real terms), leading to a steep drop in household income and to mass unemployment. Although the government promised that unemployment would not exceed 5 percent, by the end of 1993 it had reached 16 percent and was growing. Using as a stabilization target inflation (in terms of CPI) of less than 1 percent per month, the year-end inflation was about 250 percent in 1990 and over 70 percent in 1991.

The greatest disappointment among populists in political parties of the left and the right was in privatization. The higher the expectation for an egalitarian mass privatization, the greater the disappointment. As in many other transition countries, the populist anticipation that postsocialism would evolve into a "people's capitalism"- due to the wide, free distribution of denationalized assets - led to frustration

Although many people did receive free shares, they got rid of them quickly. ${ }^{5}$ Due to ongoing redistribution, the shares are now accumulated by fewer individuals, and they are oriented more

\footnotetext{
${ }^{5}$ Paradoxically, Russia has, in relative terms, more stock owners than the United States, Poland has more than Germany, and the Czech Republic more than Austria, but that does not mean there is more capitalism. In Poland, a special program of so-called mass privatization—-together with many denationalization measureshas been implemented. Over 500 state companies, with book value of about 10 percent of total state assets pending privatization, were transferred through specially established 15 National Investment Funds (NFI) to the population for a nominal fee (equivalent of US\$7, or 2 percent of the average monthly salary at the time). As many as 97 percent of eligible citizens participated in the program. Among the remaining 3 percent were, inter alia, the President of Poland, and the First Deputy Premier and Finance Minister, but they did not collect their certificates exclusively because of the lack of time. After trading at the secondary market, it is estimated that, at most, one-third of participating citizens has retained their acquired shares, while two-thirds have sold their certificates to other entities for prices 5 to 7 times higher than at the primary market. Most shares so distributed were concentrated by some institutional investors, including banks and other financial intermediaries.
} 
toward entrepreneurship and accumulation of wealth than consumption. There is nothing wrong with this type of redistribution as long as the people are not misled by their leaders, the emerging market rules are transparent, public interest is taken into account, and redistribution patterns contribute to sound development. ${ }^{6}$ Unfortunately, this has not been the case in all transition countries.

These countries also expected that the transition would bring a lessening of regional differences and tensions. In the former centrally planned economies, income levels and living standards differed significantly by region. The largest differences were seen in the former Soviet Union and former Yugoslavia. The dismantling of those countries did ease the regional tensions between the richest and the poorest former republics after they became independent, for example, between Estonia and Tajikistan in the former Soviet Union, and between Slovenia and Macedonia in the former Yugoslavia. Other countries experienced contradictory expectations, which has had significant policy implications. People living in the more backward regions expected a quick improvement in their standard of living; those living in the richer regions assumed they would be forced to transfer part of their income to the poorer regions, and they have been quite reluctant to do so. Such contradictory expectations have had significant policy implications. The larger the income gap at the outset of transition, the stronger the current tensions. ${ }^{7}$

\footnotetext{
${ }^{6}$ If one wants to take care of the long-run public interest, one should exercise a policy of simultaneously reducing both the public property and public debt. Hence, it is unwise to give up assets through any type of free distribution, without "giving" at the same time at least a proportional part of the public debt — domestic and foreign alike. From this angle, the debt-to-equity swaps should be used more widely than occurred in transition countries. The main obstacle here was again political. Under the Strategy for Poland program, the ratio of public debt to GDP fell from about 86 percent in 1993 to less than 50 percent in 1997.

${ }^{7}$ In Poland, the most difficult problem stemmed from allegations made by the industrial center (coal mines and steel mills) in Upper Silesia. Regional claims for a national income redistribution were addressed in the program, A Contract for Silesia, adopted in 1995. The program focused not on more favorable transfers but on
} 
-14 -

enhancing local activities and entrepreneurship, raising investment potential, increasing the ability to absorb FDI and better coordinating regional development policy. As a result, tensions have been eased. 


\section{REALITY}

Although income distribution varies among countries, all transition economies have some common features. Income inequality is rising in all these countries, as expected. The fluctuations in people's income - first it fell, then it grew - and in its distribution have led to higher than ever in their lifetime income inequality. The greatest changes occurred during the early stages of transition, when real income contracted significantly but at a different pace by income group. Hence, in a matter of couple of years, the income proportions have changed significantly.

From this perspective, Milanovic (1998) has divided the transition economies into three groups. In the first, consisting of Hungary, the Slovak Republic, and Slovenia (with a combined population of 18 million), income distribution, measured by the quintile relations, has not changed. No quintile group gained or lost more than 1 percentage point, so the income shift did not occur between those groups but within them. The changes were rather minor: in Hungary, the Gini coefficient went up by 2 percentage points (from 21 to 23), in Slovenia, by 3 points (from 22 to 25). In the Slovak Republic, even more equal distribution was observed in 1993-95 than in 198788, since the Gini coefficient fell from 20 to 19 points (see Table 2).

In the second group, which consists of Belarus, the Czech Republic, Latvia, Poland, and Romania (with a combined population of 84 million), moderate regressive transfers were 
Table 2. Changes in Income Inequality During Transition

1987-88 $\begin{gathered}\begin{array}{c}\text { Gini Coefficient } \\ \text { (Income per capita) }\end{array} \\ 1993-95\end{gathered}$

$\begin{array}{lll}\text { Kyrgyz Republic } & 26 & 553 / \\ \text { Russia } & 24 & 483 / \\ \text { Ukraine } & 23 & 472 / \\ \text { Lithuania } & 23 & 37 \\ \text { Moldova } & 24 & 36 \\ \text { Turkmenistan } & 26 & 36 \\ \text { Estonia } & 23 & 353 / \\ \text { Bulgaria } & 231 / & 34 \\ \text { Kazakhstan } & 26 & 33 \\ \text { Uzbekistan } & 281 / & 33 \\ \text { Latvia } & 23 & 31 \\ \text { Romania } & 231 / & 292 / \\ \text { Poland } & 26 & 284 / \\ \text { Belarus } & 23 & 283 / \\ \text { Czech Republic } & 19 & 272 / \\ \text { Slovenia } & 22 & 25 \\ \text { Hungary } & 21 & 23 \\ \text { Slovak Republic } & 20 & 19\end{array}$

Sources: UNDP (1996); Milanovic (1998).

Note: For most countries, the income concept for 1993-95 is disposable income. In 1987-88, it is gross income, since, at that time, personal income taxes were small, as was the difference between net and gross income. Income includes consumption in-kind, except for Hungary and Lithuania in 1993-95.

$1 / 1989$.

2/ Monthly.

3/ Quarterly.

4/ Semiannual. 
noticed. Maximum losses were within the range of 1 to 2 percentage points and occurred only toward the three lower quintiles. At the same time, the gains of the top quintile varied from about 6 points (for the Czech Republic and Latvia) to below 2 points (for Poland). Thus, only the highest quintile benefited, and only in terms of the share of income. Due to the severe contraction, the absolute level of real income declined in all quintiles although the higher the quintile, the lower the decrease.

In this second group of countries, the Gini coefficient rose by only 2 points in Poland (from 26 to 28 ) but by a significant 8 points in the Czech Republic (from 19 to 27).

In the third group, which consists of Bulgaria, Estonia, Lithuania, Moldova, Russia, and Ukraine (with a combine population of more than 220 million), the changes were much greater. Income decline of the bottom quintile was 4 to 5 percentage points, and the second and third quintiles lost similar margins of their earlier share. In Russia, Ukraine, and Lithuania, the fifth quintile gained as much as 20,14, and 11 points, respectively. The greatest shift occurred in Russia, where the bottom quintile share of income was halved - from 10 percent to 5 percent—while the top quintile jumped from the relative high of 34 percent to as much as 54 percent. The Gini coefficient increased by 11 points in Bulgaria, and doubled in Russia and Ukraine, jumping from 24 and 23 to 48 and 47 points, respectively (See Figure 1).

At the end of the first five years of transition, income distribution in the first and second groups of countries was, on average, still more equal than in the market economies. In the third group, however, especially in the former Soviet Union countries, income distribution continued to be less equal than in OECD member countries. 


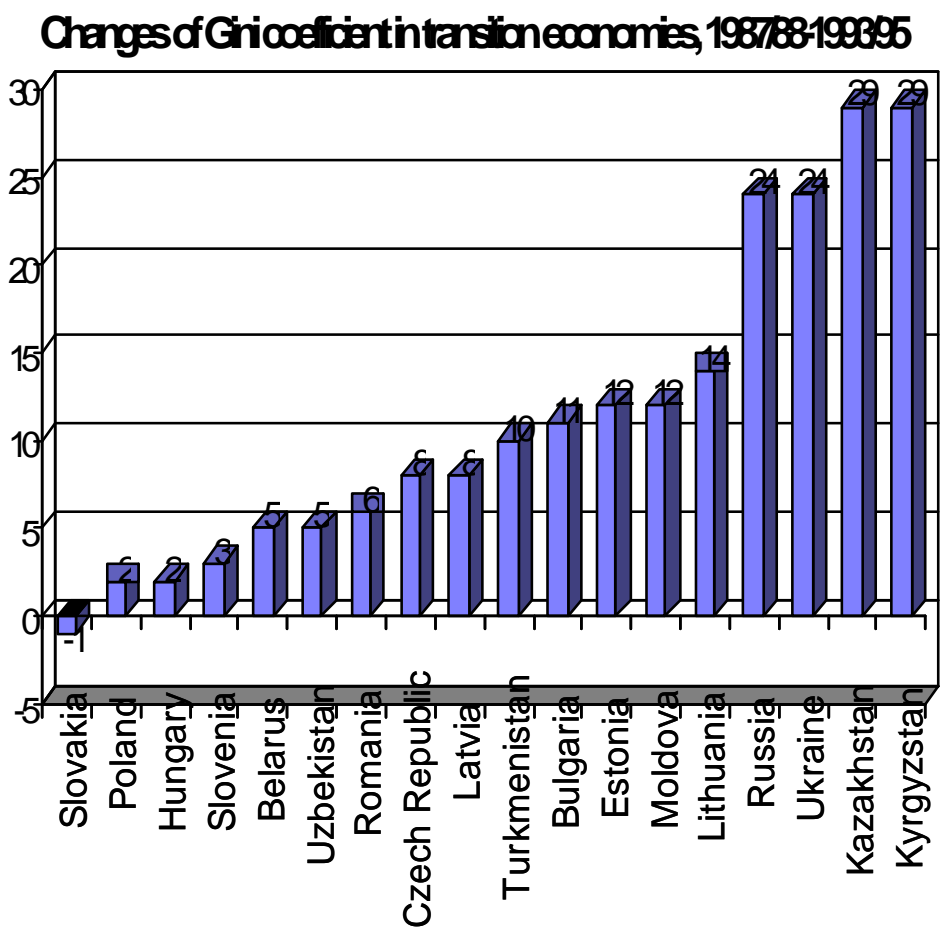


Lately, the process has taken another route. Although in most of these countries income inequality has continued to grow, albeit at a much slower pace than before, in a few, it has stabilized. In recent years, this inequality has hovered around the dispersion structure that resulted from the changes that followed the earlier shocks. Of course, the income of some households and professional groups still fluctuates, but the changes are not as remarkable as they were in the first half of the decade, that is, they no longer fluctuate between quintiles and deciles.

However, these observations must be made with proper caution. Although the transition economies are going through a vast, intensive process of liberalization, they still lack sophisticated market institutional arrangements. Thus, their common feature is an extensive shadow economy, consisting of unregistered economic activities, the income from which is significant but impossible to estimate. The shadow economy, estimated to contribute from 15 percent to 50 percent of GDP in these countries, does affect inequality. ${ }^{8}$

Because there are many types of unregistered activities, the real challenge is to find the most appropriate way to institutionalize the shadow economy. Whereas some activities should be

\footnotetext{
${ }^{8}$ For the advanced market economies, the scope of the shadow economy is estimated at about 15 percent of GDP for the European Union countries and below 10 percent for the United States. For Poland, estimates differ; although Herer and Sadowski (1996) believe that it stands at about 25 percent of the official GDP, the author estimates that it is more in the range of 15-20 percent of GDP. So, what it is in the other postsocialist countries is anyone's guess. “...Russian tax police First Deputy Director Vasily Volkovsky told Nezavisimaya Gazeta that one-third of Russian businesses are not paying any taxes, and a further $50 \%$ pay tax only occasional ly. Volkovsky said in the next few years the authorities intended to aggressively scale down the gray economy to a level at which it ceased to pose a threat to Russia's economic security. He said the gray economy accounted for 45\% of GDP in 1996" [emphasis added]. Agence France Presse, as quoted in "Russia, IMF agree on 1998 economic program,” Morning Press, April 13, 1998 (Washington: International Monetary Fund).
} 
blocked and eliminated, some others should be made official in a controlled way. The parallel economy encompasses organized crime, which has to be toughly fought, but primarily it is composed of a lot of small-scale businesses in many sectors - sectors that produce the goods and provide the services, the jobs, and the income.

In transition societies, the people being offered the opportunity to take their fate into their own hands are quite keen to do so; however, they are not that eager to register their activities and pay taxes and social security contributions on these activities. Changing such attitudes will take time. For now, however, this type of emerging entrepreneurship, which creates a reasonable source of income, should be tolerated and gradually incorporated into the official economy by various means of the "stick and carrot." Before this task is accomplished, however, a significant amount of income will be made in the shadow economy and simultaneously, a significant part of the total income will be redistributed through the parallel sector. The size of the former and the range of the latter is again, anyone's guess. These corrections in the dispersion pattern definitely complicate the picture drawn from the analysis of official income distribution alone.

At one end of the spectrum, many households engaged in the shadow economy particularly in the trade, housing construction, maintenance, and some traditional service sectors, have higher income than is recorded formally in the household budget survey (HBS). Although most-if not all —of the unemployed are officially counted in the bottom quintile, some should instead be counted in the second, at least. Given the substance of the shadow economy and the methodological problems in accurately measuring unemployment, it is obvious that an important fraction of this group makes money outside the registered economy. Therefore, their true earnings are higher than the state statistics — or even the more comprehensive HBSs—-show.

At that other end of the spectrum, the official picture may be biased even more than for the poor, because many activities of the new entrepreneurial class are not recorded at all. Using various means, they are often able to conceal from the tax officials a significant part of their actual income.

Both tax evasion and tax avoidance are widespread in transition economies, primarily due to poor tax administration and low moral standards of emerging capitalists. Whereas the creation of effective fiscal order and an efficient tax collection system is a long-lasting process, taxation is often treated as a sort of punishment. It is often believed that taxation limits the business sector's ability to expand and is rarely seen as a fair and rational instrument of income redistribution.

The range of the informal sector, with all its merits and drawbacks for income dispersion, depends on maturity of institutional arrangements, on the one hand, and developments in the real economy, on the other. In economies with relatively more advanced market institutions and a higher market culture - for example, in the countries invited to begin their accession negotiations with the EU- the scope of tax evasion is much smaller than in the countries lagging behind. Although it is difficult to measure and impossible to quantify, it seems to be feasible to claim that the shadow 
economy is larger in Ukraine than in Poland, larger in Armenia than in Latvia, larger in Romania than in Hungary, and larger in Croatia than in Slovenia.

As for real developments, the tendencies are mixed. In the fast-growing countries, at least part of the expansion is due to vigorous activities in the parallel economy, thus its impact on income levels and its structure is greater. As output rises, more people considered jobless make ends meet by working in the shadow economy than by collecting the dole from the safety net. The business communities are also able to take greater advantage of soaring shadow markets. At the same time, weak regulations allow them to hide at least part of their actual revenue. In the countries with continuing recession, an increasing number of people are looking for an opportunity to earn money wherever they can, including in the shadow economy, but they have fewer opportunities than in a growing economy.

The outcome of what has happened thus far is a puzzle and can only be roughly estimated. It is recognized that the shadow economy contributes to the higher income of all social strata, but it is impossible to estimate precisely how it influences the final proportions of disposable real income. Although the informal sector contributes to higher production and welfare as a whole, it also transfers part of the income from some households to others. Because one cannot map these income flows, one can only draw general conclusions. It is not a zero-sum game. Income redistribution conducted within the borders of the parallel economy - as well as between the parallel and the official economy — can enhance overall growth. Thus, in the long run, it can contribute to a higher standard of living for the whole society. It seems, therefore, that the parallel economy, through its contribution to actual national income, and its impact on its redistribution, raises inequality. Moreover, it may be claimed that in the transition economies, as in the lessdeveloped market economies, the difference between the official and the true picture of income distribution - if one takes into account the shadow economy — is much greater than in the more developed market economies.

\section{MECHANISM}

The income distribution pattern has changed qualitatively during transition. Some events and processes of vital importance have resulted from the elimination of a number of fundamental features and rules exercised under the centrally planned regime. In spite of considerable confusion as to what the outcome of these political, institutional and structural changes would be for equity versus inequity and equality versus inequality, the mechanism of change has been already set in motion in an irreversible way.

Particularly important is that a majority of the subsidies and allowances - previously provided by the state to some groups to support their consumption in kind-have been radically reduced or eliminated completely. Since the beginning of the transition, the removal of the subsidies has been seen as absolutely necessary by various international organizations, especially by the IMF. 
The Fund was willing to back only structural adjustment polices that led to the liquidation of all subsidies. This external pressure was mixed with domestic tugs-of-war between the countries' political extremes, that is, between the old left and the new right populists on one side, and the freemarket zealots on the other.

Depending on the social and political situation as well as on the chosen path of price liberalization and adjustment, the way the subsidies were removed influenced income dispersion. The more radical the subsidy cuts, the deeper the shift in income inequality. Whereas some shortages did indeed disappear rather quickly (the shops were full of goods), the real income and money balances of households shrank even faster (because consumers' pockets were almost empty). Consequently, the ultimate effect of slashing subsidies and price liberalization did contribute to an improvement of the fiscal stance and the introduction of a marketclearing mechanism, but it was achieved at the cost of growing inequality.

Setting aside the way the subsidy-removal policies have been executed in some countries, this approach should pay-off in the longer run. ${ }^{9}$ The transparency of free-market rules, the efficiency of market-clearing pricing and its influence upon the allocation of resources, as well as the liquidation of distribution pathologies related to the shortageflation syndrome have contributed to improving economic performance and increasing competitiveness. If not now, then in the foreseeable future, these reforms will be fruitful for all people in the transition countries and make these countries more competitive internationally.

In the meantime, however, the unavoidable part of transition—price liberalization together with far-reaching subsidy reductions_- has been causing high inflation. This was the case in Poland in 1989-93, it is still an issue in Bulgaria and Romania in 1997-99, and will be a serious challenge in Belarus and Ukraine in 1999-2001. Whether such inflation is corrective or not does not matter for additional income redistribution, due to the very diversified price adjustments on products and

\footnotetext{
${ }^{9}$ There is a long way to go in countries still at the early stage of transition, such as Turkmenistan. In the most extreme case, Belarus, shortages reappeared in the spring of 1998 due to the government's attempts at direct price control and the scope of subsidies. They, by no means will be sustainable, considering the overall state of the economy and, especially, the fiscal position of the government.
} 
services. Often, what rises first and the most is the basic cost of living - the prices of food, housing, utilities, and public transport. Later, partial commercialization (i.e., the marketization) of other basic services, including health care, leads to further increases in living costs.

Inflationary income redistribution-executed through the downward adjustment of real income by different rates per household group—significantly increased income inequality in the early 1990s. This process is far from over in countries less advanced in liberalization and stabilization (Belarus, Bulgaria, Macedonia, Romania, and Ukraine, and especially in Kazakhstan, Turkmenistan, and Uzbekistan).

With extremely high inflation, real income distribution had depended on the indexation procedures used at the time of the stabilization policy. Although the desire to stabilize the economy called for much faster growth of prices than wages - or other income, such as pensions - and hence a larger drop in the real income, social expectations and political pressure pushed the governments toward more lenient downward adjustments. Against this background, the actual indexation was always a function of political compromise, not necessarily a logical consequence of strictly economic arguments. Some social and professional groups bargained harder for compensation than others. For instance, it was easier for workers, especially in the large industrial centers, to get relatively more compensation for the growing costs of living than for teachers or paramedics.

Because of this unequal indexation, inequality continues to fuel social tensions (Gregory, 1997). Since that problem is far from solved in any transition economy, the leading countries notwithstanding, the continuing change in relative wages will continue to cause political friction. As a result, the shifts of income between certain groups will also continue, regardless of the change of these groups' contributions to the national welfare. However, in terms of inequity, these changes will not cause significant changes in the existing pattern of income distribution, only in the relative position of some professional groups vis-à-vis others.

Another aspect of inflationary redistribution that affects equity and equality deals with household savings. Because of the shortages under the centrally planned system, there was always some disposable net income that could not be spent on desired goods and services. This set in motion forced substitution and boosted the parallel, often semi-legal, or black markets. However, households were left with some residual, "disposable" income that was not "real" since it was not possible to spend it. So, it was involuntarily saved. When eventually the time for structural adjustment arrived — together with the postsocialist revolution - the prices were freed and raised to the market clearing level. However, the purchasing power of money balances, including those held in banks, was protected only partially. They were indexed, but only to some extent. ${ }^{10}$

\footnotetext{
${ }^{10}$ Dealing with the aftermath of the severe depreciation of accumulated savings is still on the policy agenda in some countries, for example, in Lithuania.
} 
The extent of the indexing depended on the stabilization programs and, of course, took into account the situation within the banking sector. Indexation was rather awkward, and when considered, with the even worse standing of the public finance system and the state budget, did not allow for full compensation. So, people's savings depreciated significantly. Only the most flexible, well-informed, and entrepreneurial households were able to protect the real value of their savings. In some of the most successful cases, these savings became the seed capital for future businesses.

In summary, many people lost part of their lifetime savings, although a few were able to convert these holdings into capital and multiply them on the wave of liberalization and the accompanying corrective inflation. This course of events has deepened income inequality in the postsocialist societies (Kolodko, 1992a); in a direct way, it has impacted solely on the savings accumulated in the past, but indirectly it influences current income and savings as well.

Economic reforms liberalized the wage setting in the state sectors. ${ }^{11}$ Regardless of the initial pace of denationalization, by the mid-1990s, in most transition economies, more than half the labor force earned their salaries in the state sector. Whereas under the socialist system, due to ideological and political constraints, the dispersion of wages was quite limited, a much wider dispersion has been accepted during the transition. Thus, income has become more tightly linked to qualifications, experience, occupation, and performance. The transition has meant a closer relation between an individual's past investment in human capital and its current remuneration, which has led to greater wage dispersion (Cornia, 1996a). Because the quality of human capital varied more than did salaries under central planing, the later realignment of wages with levels of human

\footnotetext{
${ }^{11}$ In some countries $\rightarrow$ such as the former Czechoslovakia and Romania, which initiated market reforms at the onset of 1990s - economic reforms have caused more fundamental changes. In others $\rightarrow$ such as Hungary and Poland, which started reforms and wage deregulation much earlier-this process was only (yet significantly) accelerated.
} 
capital has increased income inequality. It may, however, be claimed that income equity increased as well. That is true for both blue-collar and white-collar workers. ${ }^{12}$

Even more significant for rising income inequality is the shift of labor from the state to the private sector. Not only is the dispersion of wages in the latter larger than in the former, but the average income earned is higher. This is due mainly to the higher labor productivity in the private sector as the state is in control of a number of obsolete, noncompetitive industries and poorly managed, relatively low paid services, such as education, health care, and central and local administrations. Because of the meager budgetary situation, these sectors have not been able to compete with remuneration provided by other industries, performing profitably on a commercial basis. Therefore, the rising share of labor engaged in the rapidly growing private sector has raised income inequality. This is merely a reflection of the accommodation of the market to the higher quality of labor engaged in these activities. Nevertheless, in transition economies, to the extent that the labor market is still quite rigid and far from perfect, the salary ratio remains somewhat distorted.

When an economy moves from the centrally planned to the free-market system, the most revolutionary and fundamental changes take place in asset ownership. The basic features of the beginning of capitalism after socialism are denationalization, privatization, property restitution, participation of foreign direct and portfolio capital and the development of financial intermediaries to accompany private sector's expansion. These events have a major impact on changes in income distribution.

\section{During transition, the share of wages in total income decreases, while that of} capital gains-for example, profits, dividends, interest, and rents-increases. This process itself contributes significantly to growing inequity as well as inequality. Market reforms inevitably result in some unjustified redistribution, as it is an unavoidable byproduct of the transition process. Whereas limiting the range of the postsocialist redistribution is a matter of sound policies, containing and regulating it entirely is simply impossible.

\footnotetext{
${ }^{12}$ Although during the socialist era it was accepted that the ratio of state-determined wages between unskilled workers and university professors should not exceed, approximately, 5:1, during the transition—if the market so determines - this ratio may exceed, approximately, 15:1.
} 
The fundamental shift of assets from state to private hands has been followed by a shift in the income earned on these assets in the same direction. Obviously, these changes have also increased the inequity and inequality. Therefore, one must decide how the property rights transformation is to be designed and by what means it will be managed? The two options would be, at one extreme, to sell state property to any investor, especially a strategic one, at the marketclearing price, ${ }^{13}$ and, at the other extreme, the utopian option of freely distributing all assets among eligible citizens. ${ }^{14}$ Of course, in the real world, some combination of the two extremes is needed. Hungary chose a path closer to the first option; the Czech Republic, closer to the latter; and Poland, between the two.

The implications for corporate governance and microeconomic efficiency differ by option, but so do the consequences for income inequality in the long run. And the choice between the two options is not simple. More unequal privatization, by selling to strategic investors, favors competitiveness and hence the income level, whereas more egalitarian distribution of assets favors income equity but does not necessarily improve efficiency.

\footnotetext{
${ }^{13}$ That is fine if the assets are sold at market clearing prices, but often they are not. And, if not, who is eligible to acquire the assets pending denationalization? When the author asked in 1993 the then deputy minister of finance in charge of the privatization of Poland's financial institutions why they were selling the shares of Bank Slaski at many times below the marketclearing price, he was told that the reason is simple: to provide the new owners with enough capital gains that they will soon be able soon to acquire the next bank. And they were. The Bank Slaski shares, a couple of months later on the floor of Warsaw's stock exchange, were traded at more than 13 times the asking price by the Ministry of Finance on the primary market? The budget had lost a lot, but a few had gained a lot as well. And the Minister of Finance was fired.

${ }^{14}$ The point is that assets distributed on the primary market—for free or for a nominal, symbolic fee—are sooner or later redistributed on the secondary market. Again, people are free to do so, but in the end it leads to the accumulation of these assets by only a few.
} 
The populist mainstream in both economics and politics has suggested that mass privatization through the free distribution of shares can offset the hardship caused by structural adjustment, especially growing unemployment and falling real earnings and pensions. This may be true, but only to some extent and only as temporary compensation for lost income. In fact, in several countries, workers have gone on strike - not against privatization but in favor of it. These strikers were not zealots of capitalism and a free market; they just wanted quasi-money-the shares or the vouchers, certificates, and coupons, entitling them to shares' - which they felt was rightly theirs. However, it is bizarre that a poor person would have no access to an adequate social safety net yet, owns one or two shares of a privatized enterprise. This poverty and lack of social protection did not accord with the vision of market economy under "people's capitalism;" furthermore, it barely reduced the inequality and resulting tension. ${ }^{15}$

The problem of equity and equality versus inequity and inequality, is even more serious. The basic problem is not the change in the income distribution pattern in, say, 1990-99-although for some 15 percent of the population these are their last years - but the irreversible foundation that has been laid for income distribution in the future. This change is the result of the stormy and indeed badly regulated and controlled process of asset distribution linked to the privatization process. In other words, when some were fighting for more fair indexation of their modest income (i.e., the current flow), the more cautious were trying to acquire as much property as possible (i.e., stock, or future income).

In conclusion, taking only the flow of income into account, one cannot accurately answer the question about the scope, direction, or pace of inequality. Those that are, in fact, rich (owning many assets) may report very little income, whereas somebody else — a relatively poorer person — can pay the highest possible taxes. To properly measure inequality, one must analyze not how the flow of income is dispersed, but how it is distributed and how the stocks of denationalized assets are divided. Otherwise, one will get a distorted picture, if not false, like from watching only part of the movie screen. Unfortunately, there is not even a rough statistical basis for such considerations. Most income flows are registered, but asset transfers are not.

\footnotetext{
${ }^{15}$ Juha Honkkila (1997, p. 6) rightly claims that "for individuals brought up in a communist society, the loss of safe employment or other social benefits provided by the state sector cannot be offset by minor opportunities to enjoy the personal ownership of assets."
} 
The introduction of comprehensive taxation systems has change d the income distribution mechanism and its final outcome. Fiscal order in transition countries is not yet the same as in the mature market economies. The personal income tax - for some countries, entirely new - is always progressive, although the brackets and scales vary by country and can change in either direction. Because higher income is taxed at a higher margin, taxation decreases the net disposable income gap between better and worse-remunerated people and, subsequently, narrows the scope of inequality.

In transition economies, the fiscal regimes and policies are not stable and hence neither is the equalizing effect of fiscal policy. There are continuous debates and political battles between the parties on raising and lowering the taxes and, of course, at the same time. Again, the true system is never a masterpiece of public finance theory and policy, but always a political compromise.

In spite of these reservations, it should be noted that redistribution does, at least to some degree, contribute to an impartial correction of the primary income distribution. As the market is in the process of being born, it cannot, of course, distribute national income in a way that guarantees both the fair participation of specific groups in the flow of current wealth and its future growth.

What makes transition countries truly different from advanced market economies is that, in most cases, capital gains are not taxed at all. As they are not taxed, they are not recorded. Or is it the other way around? This approach has serious policy implications, but regarding the fiscal system's impact on equity and equality, the lack of capital gains taxation definitely increases inequity and inequality.

\section{POLICY}

The heart of the transition matter is to change a stagnant, former centrally planned economy to a market economy that can expand and compete internationally. Other issues, including income and wealth distribution, are often seen as secondary goals of economic and social policies, or simply as byproducts of the systemic changes. Besides, the redistribution of income can be treated as simply a means of superior policy of the overhaul of the system, that is, the radical alteration of the distribution pattern serves only as an instrument for the further accumulation of wealth. And such accumulation, in turn, should create a foundation of the new middle and upper classes, without whom the market system cannot exist. In fact, in transition economies one can observe the frantic process of wealth accumulation, which can be called postsocialist primary capital accumulation If not immediately then soon thereafter, people get the message that capitalism cannot be restored or created without capital and capitalists — and the inherent consequences for inequity and inequality.

The conclusion is obvious. During transition inequality must rise, and policymakers should try to shape such inequality in a way that facilitates the transition's goals. Thus, the 
challenge is, first, to define and design this line of policy, and, second, to implement it in the best possible fashion. This is not easy; it may be even more difficult than it was in the past during periods of primary accumulation, because now it must take place during a severe transitional recession.

Whatever the explanation for the great postsocialist slump, ${ }^{16}$ the fact remains that the officially registered GDP of 25 countries in Eastern Europe and the CIS has contracted by almost 30 percent (weighted average) in the first seven years of transition. Only in the eighth year - in 1997—was a modest recovery recorded, albeit not in all countries involved (see Table 3). ${ }^{17}$

From social and political points of view, it is a challenge — and rather risky, politically — to allow for any meaningful shift of income from the bottom to the top quintile, even at the time of robust growth. Certainly, it is much more difficult to do so during a period of collapse in output. For the transition, the latter has been the case for a number of years. Therefore, in considering the issue of inequality, one has to distinguish between the stages of contraction and growth.

\footnotetext{
${ }^{16}$ For different views on this subject see, inter alia, Bruno (1992); Kornai (1993); Lavigne (1995); Gomulka (1996); Blanchard (1997); and Kolodko and Nuti (1997).

${ }^{17}$ According to IMF estimates, in 1997 GDP for the whole region increased by a modest 1.7 percent and should grow by 2.9 percent in 1998. This year, for the first time since the transition began, none of these countries is to undergo a decline in output. The overall expansion is expected to increase further in the medium term (IMF, 1998). It is worth noting that, in the past, the Fund, in its annual World Economic Outlook, wrongly predicted a turnaround.
} 
Contraction has lasted from a relatively short period of three years in Poland ${ }^{18}$ to eight years in Ukraine. ${ }^{19}$ In some countries — and not only those experiencing regional conflicts-it may continue for some years. While the average income is on the decline and policy favors promotion to the new middle class, poverty must also be increasing. During the period of contraction, the redistribution mechanisms transfer additional portions of already falling income from the poorer parts of society to the richer.

\footnotetext{
${ }^{18}$ Between mid-1989 and mid-1992, the GDP in Poland contracted by about 20 percent and the industrial output by more than 40 percent.

${ }^{19}$ During these eight years (1990-97), the official GDP decreased by as much as 58 percent, which is much more than in any other country during peacetime.
} 
Table 3: Recession and growth in transition economies: 1990-97

\begin{tabular}{|c|c|c|c|c|c|c|c|}
\hline \multirow[b]{2}{*}{ countries } & \multirow{2}{*}{$\begin{array}{c}\text { number of } \\
\text { years } \\
\text { of GDP } \\
\text { decline }\end{array}$} & \multirow{2}{*}{$\begin{array}{l}\text { did GDP } \\
\text { fall again } \\
\text { after } \\
\text { recovery? }\end{array}$} & $\begin{array}{c}1990- \\
93 \\
\end{array}$ & $\begin{array}{c}1994- \\
97 \\
\end{array}$ & $\begin{array}{c}1990- \\
97 \\
\end{array}$ & 1997 & \multirow[t]{2}{*}{ Ranking } \\
\hline & & & \multicolumn{3}{|c|}{$\begin{array}{c}\text { (average annual rate } \\
\text { GDP growth) }\end{array}$} & $\begin{array}{l}\text { GDP index } \\
(1989= \\
100)\end{array}$ & \\
\hline Poland & 2 & no & -3.1 & 6.3 & 1.6 & 111.8 & 1 \\
\hline Slovenia & 3 & no & -3.9 & 4.0 & 0.0 & 99.3 & 2 \\
\hline Czech Republic & 3 & no & -4.3 & 3.6 & -0.4 & 95.8 & 3 \\
\hline Slovakia & 4 & no & -6.8 & 6.3 & -0.3 & 95.6 & 4 \\
\hline Hungary & 4 & no & -4.8 & 2.5 & -1.1 & 90.4 & 5 \\
\hline Uzbekistan & 5 & no & -3.1 & -0.3 & -1.7 & 86.7 & 6 \\
\hline Romania & 4 & yes & -6.4 & 2.1 & -2.2 & 82.4 & 7 \\
\hline Albania & 4 & yes & -8.8 & 4.9 & -2.0 & 79.1 & 8 \\
\hline Estonia & 5 & no & -9.7 & 4.1 & -2.8 & 77.9 & 9 \\
\hline Croatia & 4 & no & -9.9 & 3.0 & -3.4 & 73.3 & 10 \\
\hline Belarus & 6 & no & -5.4 & -2.6 & -4.0 & 70.8 & 11 \\
\hline Bulgaria & 6 & yes & -7.4 & -3.6 & -5.5 & 62.8 & 12 \\
\hline Kyrgyzstan & 5 & no & -9.3 & -2.4 & -5.8 & 58.7 & 13 \\
\hline Kazakhstan & 6 & no & -6.7 & -6.0 & -6.3 & 58.1 & 14 \\
\hline Latvia & 4 & yes & -13.8 & 2.2 & -5.8 & 56.8 & 15 \\
\hline Macedonia & 6 & no & -12.9 & -0.8 & -6.9 & 55.3 & 16 \\
\hline Russia & 7 & no & -10.1 & -5.3 & -7.7 & 52.2 & 17 \\
\hline Lithuania & 5 & no & -18.3 & 0.5 & -8.9 & 42.8 & 18 \\
\hline Turkmenistan & 7 & no & -4.5 & -15.0 & -9.8 & 42.6 & 19 \\
\hline Armenia & 4 & no & -21.4 & 5.4 & -8.0 & 41.1 & 20 \\
\hline Azerbaijan & 6 & no & -14.5 & -5.7 & -10.1 & 40.5 & 21 \\
\hline Tajikistan & 7 & no & -12.2 & -8.4 & -10.3 & 40.0 & 22 \\
\hline Ukraine & 8 & no recovery & -10.1 & -12.1 & -11.1 & 38.3 & 23 \\
\hline Moldova & 7 & no & -12.6 & -10.2 & -11.4 & 35.1 & 24 \\
\hline Georgia & 5 & no & -24.1 & 2.9 & -10.6 & 34.3 & 25 \\
\hline
\end{tabular}

Source: National statistics, international organizations and author's own calculations. 
This is the picture as seen from a macroeconomic perspective. On the micro level, however, the changing pattern of income flow reflects mostly the shift in certain population groups' contributions to GDP. This product unfortunately, has been shrinking for several years. The poor are getting poorer because their contribution to declining national income is falling faster that the contributions of other groups. The shorter this extremely difficult period, and the smaller the fall in output, the better. It may be argued that both the scope and the length of the transitional recession, which is, to some extent, unavoidable could be reduced (Kolodko, 1992b). Hence, the first general conclusion is that in addressing the issue of inequality in transition countries, one must try to limit the scope and length of the recession as much as possible. Avoiding a recession is not possible, but counteracting it is necessary.

Sooner or later, the transition economies will grow. After all, the whole exercise is motivated by a commitment to bring them into the global economy as open markets that can expand much faster than before. The World Bank (1997) estimated that the transition economies could grow in a quarter of a century (1996-2020), by as much as 5.8 percent annually. Although that may seem impossible - especially in light of the weak performance of 1996-97, which showed almost no growth at all — some countries may achieve even more; it depends on the quality of the policies. With sound fundamentals, proper institutional arrangements, active involvement of the redefined state-and some luck — it may happen.

Recently the leader in the transition, Poland, has enjoyed a remarkable rate of growth. Under a properly fashioned program known as the Strategy for Poland, ${ }^{20}$ which covers both transition and development, the economy has moved from early "shock without therapy" to "therapy without shock." Not surprisingly, in 1994-97, Poland recorded a GDP growth of about 29 percent, or 6.4 percent on average. This growth was accompanied by further progress in institutional advancement, which brought Poland to OECD membership in the summer of 1996 and, together with five other Eastern European nations, to EU accession negotiations in March 1998. At the same time, further progress toward the consolidation of stabilization into stability has been accomplished. Inflation fell threefold, from 37.7 percent at the end of 1993 to 13.2 percent at the end of 1997; the unemployment rate declined by more than one-third, from 16.4 percent to 10.5 percent; and the fiscal-deficit-to-GDP ratio was halved from 2.8 percent to only 1.4 percent.

When an economy is on the rise, the issues of inequity and inequality can be addressed in a different way. During a recession, the question is, How can the loss of income be shared? or, How can particular social groups participate in its decline? Under an expansion, the question can be modified to, How should growing income be distributed?, or, in other words, How should the increment in national income be divided between population groups? Even in the most advanced market economies, policy affects how income is shared, as it cannot be left exclusively to

\footnotetext{
${ }^{20}$ See Kolodko (1996); and OECD (1996).
} 
spontaneous market forces. And more so in transition countries, where the market forces are, by definition, in their infancy. The best policy guideline for the government is to intervene only to the extent that guarantees a compromise between the interests of particular income groups and provides sufficient incentives for capital formation to facilitate development and hence the growth in the standard of living for all (Tanzi and Chu, 1998).

A group that is definitely gaining from recovery and growth are those who have found jobs. In Poland's case, unemployment peaked in the summer of 1994 at close to 17 percent, or almost 3 million people. By the end of 1997, due to an active employment policy that took advantage of both directed subsidized credit and fiscal instruments, joblessness fell by 1 million. These 1 million people and their families have improved their absolute and relative income positions and thus the previous income inequality has been mitigated. Hence, the second general conclusion is that only a policy that lowers unemployment can reduce inequality.

The income policy as well as the asset redistribution policy must facilitate the accumulation of capital, which is mainly the domain of richer people. During a period of strong growth, it seems to be easier to accomplish this target because the two policies benefit each other-although only in the medium and long term. Growth facilitates capital formation and, vice versa, capital formation favors growth. If these interrelations are set in motion by the policy instruments and events in the real and financial sectors, then easier is to get society's approval for such policies.

If some are getting richer while some are getting poorer-which is unavoidable during periods of contraction and thus increasing inequality - there is no way to convince the latter that they are better-off. ${ }^{21}$ If one is poor, but a little less so than before-because someone else who is now richer is contributing to overall growth — one accepts the situation. It may — and it willhappen that on such a path, the income dispersion will increase even more. Nevertheless, if the increase in the wealth of some does not occur at a cost to others, these changes are likely to be accepted by most of society.

These attitudes can be seen in the public's reaction to changes in the standard of living and income distribution in two distinct transition economies. One seems to be a success story, the other one is, so far, a failure. In the first country, Poland, the percent of households that assess their

\footnotetext{
${ }^{21}$ In 1991, an advisor to the Polish government was asked to name the greatest achievement of the stabilization program. His answer was that kiwis can be bought on Warsaw's streets. In 1997, another advisor said that in Russia there was already a market economy (which, of course, is supposed to serve society better than the previous system), but that people were not yet able to understand it. The problem is that the market economy consists not only of private property and liberal market rules, but must also have sound institutional arrangements, a market culture, and appropriate behavior by the people. Thus, as long as people do not understand what a market economy is, they do not have a market economy.
} 
situation as "good or very good" is slowly but steadily growing. It rose from a single digit in the early 1990 s to 12.2 percent in 1995 and to 13.1 percent in $1997 .^{22}$ This change in public opinion reflects both the growth of absolute income as well as greater acceptance of changes in the income distribution pattern. So, not only does the reality change, but the public's perception of it changes as well.

\footnotetext{
${ }^{22}$ Data from the HBS provided by the Central Statistical Office (see GUS, 1997a, p. 6).
} 
In the second country, Russia, the public is convinced—and not without a cause - that transition has brought a plague of corruption and "crony capitalism," which are related to the continuing recession, growing inequality, and spreading poverty. Even the country's leading politicians and international organizations have admitted on several occasions that this is indeed the case. $^{23}$ Consequently, the Gini coefficient doubled in the first five or six years of transition and will likely rise further. The growing arrears on unpaid salaries and pensions, on the one hand, and the accumulation of wealth from insider privatization, lucrative financial market deals and especially pervasive organized crime, on the other hand, have contributed to the increasing income inequality. Both reality and beliefs are reflected in the very discouraging public opinion. When between 80 percent and 90 percent of society is convinced that wealth accumulation depends on connections or dishonesty and that poverty is a result of the economic system, then the future does not look bright (see Table 4).

In contrast, in Poland, due to the robust growth initiated by the Strategy for Poland and an income policy aimed at achieving more fair distribution— the Gini coefficient has stabilized in recent years. According to an OECD study, it grew from about 25 percent in 1989 to about 30 percent in 1994, then declined slightly to 29.4 percent in 1995 (OECD, 1996). Estimates show that the Gini coefficient has remained around this level since or has increased only slightly in terms of wage dispersion, but that it has increased rather substantially in terms of income per capita (see Figure 2).

\footnotetext{
${ }^{23}$ In 1997, the then First Deputy Prime Minister, Boris Nemtsov, during his first days in the office made a point that Russia must choose between "bandit-capitalism" and "capitalism with a human face". The Managing Director of the European Bank for Reconstruction and Development, Jacques de Larosiere, claimed at the EBRD 1997 annual meeting that with respect to Russia and other former Soviet Union republics, in 1996 alone the outflow of capital from the region probably exceeded the total invested by the EBRD since its creation (Financial Times, 1997). Most of this outflow is believed to be linked to illegal economic activities, organized crime, and money laundering.
} 
Table 4. Russia: Placing the Blame

(What are the causes of poverty?)

\author{
Poverty \\ (In percent) $1 /$
}

$\begin{array}{ll}\text { Economic system } & 82.0 \\ \text { Laziness and drinking } & 77.0 \\ \text { Unequal opportunities } & 65.0 \\ \text { Discrimination } & 47.0 \\ \text { Lack of effort } & 44.0 \\ \text { Lack of talent } & 33.0 \\ \text { Bad luck } & 31.0\end{array}$

Wealth

(In percent) $1 /$

$\begin{array}{ll}\text { Connections } & 88.0\end{array}$

$\begin{array}{ll}\text { Economic system } & 78.0\end{array}$

$\begin{array}{ll}\text { Dishonesty } & 76.0\end{array}$

$\begin{array}{ll}\text { Opportunities } & 62.0\end{array}$

Talent $\quad 50.0$

Luck $\quad 42.0$

$\begin{array}{ll}\text { Hard work } & 39.0\end{array}$

Source: Survey by InterfaxAIF of 1,585 respondents (Moscow, November 1997).

1/ Percentage of respondents agreeing to each cause.

Likewise, the decile ratio increased to 3.03 in 1993 and 3.36 in 1994; since then it has stabilized or risen by only a small margin. More meaningful changes have occurred within the top decile, due to wealth accumulation by the richest, but the actual income for the top ventile is unknown (World Bank, 1995). One must be careful in drawing conclusions from these observations. Particularly at the top of the top decile, the picture can be seriously distorted and the 
difference between the decile (or ventile) ratio for wages and for overall income seems to be indeed significant (see Figure 3).

\section{Gini coefficients during implementation of Strategy for Poland}

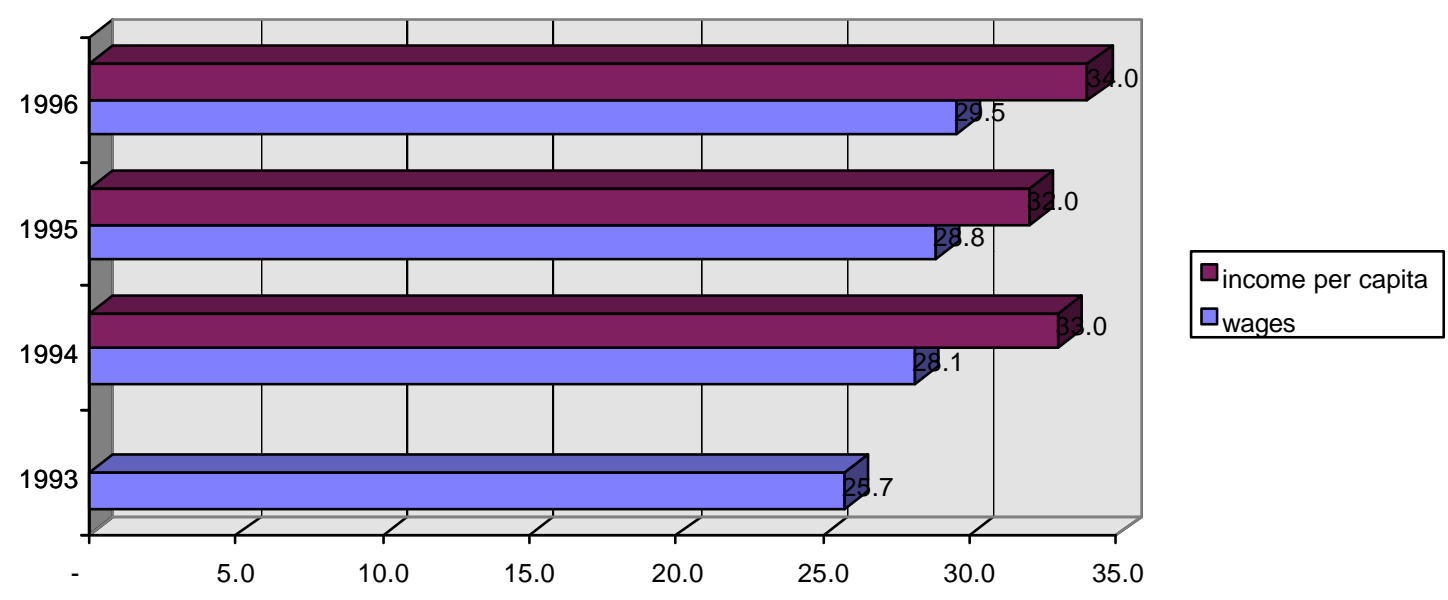


Decile ratio for wages in Poland, 1993-96

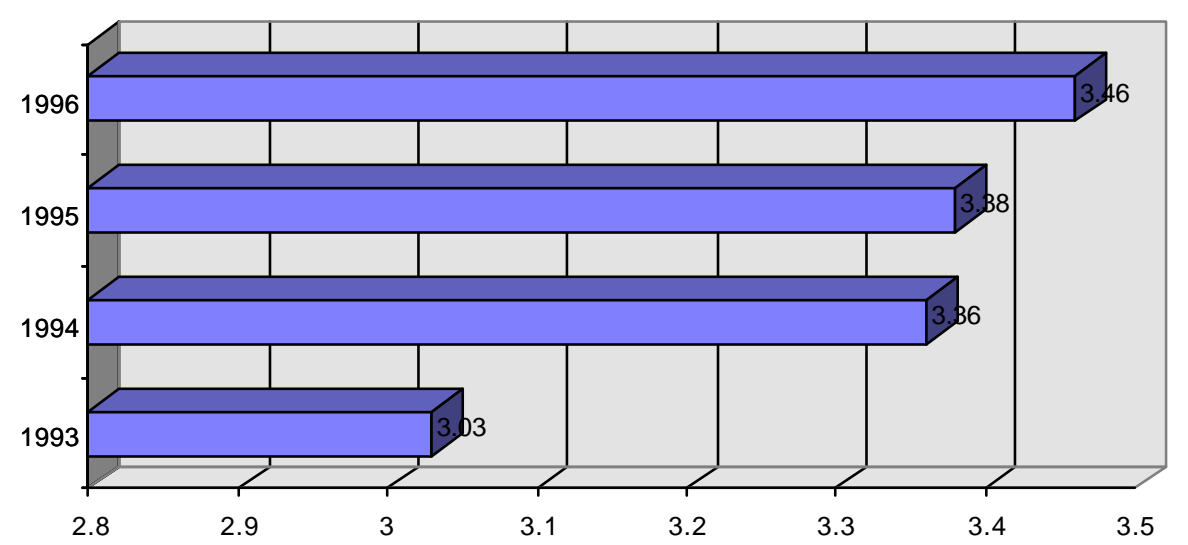


Has this recent drive toward more equitable income distribution in Poland been just a coincidence or the result of a deliberately chosen policy? Both. On the one hand, the market forces, set in motion by the transition changed the distribution mechanism (Cornia and Popov, 1997). Developing economies with fast-expanding private sectors and the simultaneous restructuring of state industries have been able to provide growing income for all social strata. As far as the decile groups are concerned, since 1995, their gains have been rather proportional. ${ }^{24}$ On the other hand, a decision was made and became a fundamental part of the Strategy for Poland, that more fair income distribution should be not only the autonomous policy target but also an instrument to facilitate further growth.

At the beginning of the transition, the shift of labor from the state to the private sector quickly caused an increase in wage inequality. This worsened when discriminatory measures were used against the state sector. Tough, if not too restrictive, wage-based taxation was used to contain nominal salaries; this was an essential instrument of anti-inflation policy at this stage. Later, especially in 1991-93, the famous Polish popiwek, that is, the wage-based punitive tax, was used exclusively as leverage on state companies to push them toward privatization. Although the popiwek served this purpose, it also facilitated increasing income disparity and hampered the motivation for labor productivity growth in the public sector.

\footnotetext{
${ }^{24}$ Of course, this hypothesis should be carefully re-examined when more data on income dispersion for 199698 becomes available.

${ }^{25}$ Some claim that too great an income inequality acts against growth (Alesina and Perotti, 1996; and Alesina, 1997). Transition economies are no exception in this respect.
} 
So, when the popiwek was finally abandoned at the beginning of 1995, state sector output soared. As a result, the growth in the income of the workers employed in this sector was on a par with the growth of remuneration in the private sector. Thus, the third general conclusion is that it is unwise to use a punitive measure that favors one sector at a cost to another even if it accelerates privatization, because it may slow the rate of growth and stifle competitiveness not only in the state sector but throughout the economy. If such a measure is used, inequality will rise and growth will slow in the medium term. ${ }^{26}$

Another important policy challenge was related to income policy at the initial stage of structural adjustment within inflationary surroundings. In 1990, at the beginning of the stabilization, attempts were made to contain aggregate demand by cutting the civil servants' wages by a larger margin than the fall in the remuneration of the industrial workers. Later, the objective was to increase more quickly the average compensation to civil servants. This move was based not only on the conviction that such compensation was more fair but also that this type of investment in human capital would contribute to higher growth in the long term, and strengthen the relationship between investment in human capital and earning levels, which was rather weak prior to and at the beginning of the transition. Therefore, the fourth general conclusion is that although the regulation of commercial sector wages should be left basically to market forces, the state should keep civil servants remuneration at an optimal ratio to the average industrial wage, and this proportion must be at a socially acceptable level, and facilitate the de velopment of human capital in the long term. Fiscal policy should serve this purpose as well.

A further shift in policy was linked with difficult issues of indexation of pensions and benefits for the disabled. At the beginning of the stabilization, instead of indexing pensions to the cost of living, they were indexed to nominal wages. This was another serious policy mistake, since the solution was short-lived (Kolodko, 1991). This indexation was based on the assumption that real pensions should follow the path of wage adjustment - there should be a steep fall in real wages and a simultaneous deep contraction of real pensions.

\footnotetext{
${ }^{26}$ It has to be stressed that in the Polish success story, the acceleration of growth in 1994-97 was mainly due to the gradual privatization, the fast-growing new private sector, and the commercialization of state enterprises (OECD, 1996; Poznanski, 1996; Kolodko and Nuti, 1997).
} 
However, as soon as wages began to increase, due to growing labor productivity, so did pensions, despite the lack of financial sources to pay for such increase. Because the government was forced to borrow to finance the expanding fiscal gap, the commercial sector was crowded out of the credit market. This, in turn, acted against potential growth. It would have been much more reasonable to first decrease real pensions by less than the drop in wages, then allow them a smaller growth in real terms. Afterward, it turned out to be extremely difficult to adapt the indexation rules to the new circumstances, which has serious consequences for the public finance stance and delays the social security system reform. ${ }^{27}$

\footnotetext{
${ }^{27}$ Nevertheless, the comprehensive social security system reform was prepared and launched within the framework of the Strategy for Poland, but not until 1997.
} 
In 1996, modification of the indexation rules allowed for real pensions to be adjusted upward yet kept within the limits of noninflationary financing; this has led to only a moderate increase in the ratio between average salaries and pensions. Considering the very high dependency ratio, these reforms did not significantly change the income dispersion. ${ }^{28}$ Contrary to popular belief in Poland, only about 15 percent of retired people are poor, or worse-off than the working class. ${ }^{29}$ Therefore, most pensioners are actually in the second or third quintile, a fact sustained by the new indexation rules, which allow for a modest growth in purchasing power.

Crucial to the success of transition and development is a capital formation policy. It is assumed that a market economy, unlike a centrally planned economy, will be characterized by a greater ability to save and a more efficient allocation of capital. In the past, however, the severe output collapse caused a substantial decline in the propensity to save and the emerging postsocialist markets were caught in the trap of serious capital deficit. Although the inflow of foreign savings is important, especially long-term capital and preferably as direct investments, domestic savings are even more so.

During transition, income policy must deal with many contradictions. Although the drive to encourage saving suggests more lenient taxation of some types and sources of income, growing inequality suggests the opposite. How to solve this alternative, that is precisely a matter of policy options. If the economy is expected to recover quickly and expand, then some fiscal preferences for capital gains have to be introduced. This option is politically difficult not only because of quite strong populist temptations in the postsocialist societies as well as among influential politicians, but also because it is strange to tax unemployment benefits or minimal pensions yet not capital gains on speculation, for instance on the stock exchange.

\footnotetext{
${ }^{28}$ A relatively high dependency ratio is common to all transition economies. Although in Poland, due to another miscalculation of the early stabilization policy, many older people were given early retirement. Hence, at the onset of the transition (1990-91), the size of the retired population jumped significantly, despite the natural demographic tendencies that would suggest otherwise. Since that period, the average retirement age has fallen to as low as 59 years for men and 55 years for women.

${ }^{29}$ This is more the result of the assets accumulated in a lifetime than the effect of the current income flow.
} 
Often in transition economies, in fact, such policies are exercised for the sake of raising the propensity to save. The capital gains from, for instance, the appreciation of stocks, interest on bank deposits, dividends on shares, are mostly free of taxation or taxed only modestly, with the rationale of promoting capital formation and increasing national saving. ${ }^{30} \mathrm{Of}$ course, this approach increases inequality but also — through saving and investment-facilitates growth and, hence, the future standard of living of the entire nation.

At the beginning of a transition, especially during a contraction, the above-mentioned capital formation policy worked for only the more affluent, namely, those who have disposable income from which a fraction can be saved and invested. Later, when the economy is on the rise and more social strata are enjoying growing real income, the expanding capital markets and better performing financial intermediaries, together with a preferential fiscal policy, encourage further saving. Consequently, the size of the emerging middle class increases and the poorer parts of society are able to save a growing percentage of their earnings.

As expected, this policy was quite controversial in Poland. In late 1992 through 1993, the lack of taxation on gains from stock speculation and a general euphoria led to an expanding bubble in the capital market. This situation - typical for emerging markets - was fueled by the frantic mass media. The rate of return, although not sustainable, was extremely high, thus, demands for the taxation of extraordinary profits earned during a period not that favorable to the overall economy, seemed to be justified. Unfortunately, no corrective steps were taken until it was too late- the bubble burst at the beginning of 1994. The stock exchange index declined by some two-thirds, at which point there was no reason to tax this type of capital gain, if there was any. For a couple of months, a rather neutral turnover tax was imposed on short-term stock exchange transactions, but it was soon eliminated.

In 1996, the Polish government adopted Package 2000, a program aimed at sustaining growth; under this program, capital gains remain tax free at least until the end of 2000. Between 1993 and 1997, national savings increased by about 4 percent of GDP, mostly from higher domestic savings. If such actions had not been taken, perhaps inequality would be slightly less, but growth would not be as robust. Thus, the fifth general conclusion is that, if the policy alternative is less inequality and a lower rate of growth, or greater inequality and a higher rate of

\footnotetext{
${ }^{30}$ In Poland, dividends are taxed, but at the relatively low rate of 20 percent, which matches the lowest personal income tax bracket; the corporate income tax rate is currently 36 percent.
} 
growth, then the choice should be higher growth and acceptance of a relatively higher income disparity. In the end, everyone will be better-off if this policy is chosen.

Package 2000 reduced corporate and personal income tax for all income groups. Prior to 1996, the corporate income tax was a flat 40 percent, but since 1997, it is being cut by 2 percentage points per year, to 32 percent in the year 2000 and afterward. These rate changes should enhance corporations' ability to invest and, in the longer run, increase international competitiveness.

Package 2000 reduced the personal income tax in two steps. ${ }^{31}$ First, after a parliamentary compromise, each of the three brackets was lowered in 1997 by 1 percentage point - to 20, 32, and 44 ; in 1998, they have been cut to 19,30 , and 40 percent.

\footnotetext{
${ }^{31}$ Earlier, at the beginning of 1994, the personal income tax had been raised from 20, 30, and 40 percent to 21, 33 , and 45 percent, respectively .
} 
Once again, there was a hot political debate on making these tax cuts. Strong opposition to the proposed cuts emerged in both the ruling coalition and among their political opponents. ${ }^{32}$ For the corporate tax, in government circles it was argued that it would be better to widen the existing system of tax deductions, which was aimed at promoting investment, than to lower the tax burden for all enterprises. Opponents argued that it would be better to give up the entire system of investment allowances and lower the tax rate even further.

As for the personal income tax, the leading argument of the parties supporting the government was that the proposal favored the richer part of society, providing them a nominal tax reduction of as much as 5 points, whereas for the overwhelming majority of the population it would be only 1 point. But it must be remembered that personal income taxes had been raised previously by these very margins.

The attitude of the opposition liberal party was a bit strange. Although they declared their strong probusiness orientation, they simply did not want the tax reduction plan to be realized by a government led by the leftist party, which-according to their rhetoric motivated by ideology and politics - was supposed to be in favor of taxing and spending. Eventually, the reduction of the lowest bracket was raised to 2 percentage points and some minor changes were made in deductions linked to investment in human capital, particularly in higher education. This scheme was accepted.

\footnotetext{
${ }^{32}$ The author, who was at that time First Deputy Premier and Finance Minister, liked to say, "I don't need any more opposition—I have enough from my own coalition."
} 
As for income distribution, these changes in the tax code may raise inequality slightly, especially the ratio between the tenth and the other deciles. Although all taxpayers will gain from the reduction of the fiscal burden, the top decile will gain more than the other nine. Income dispersion and the personal taxation system in Poland work in such a way that only those in the top decile for at least a few months pay taxes in either of the two upper brackets ( 30 and 40 percent). ${ }^{33}$ Hence, their net income increases more than that of the remaining 90 percent of society. The final results of these changes will not be known until after 1999, when the first year's gross personal income and tax records are available.

In spite of the drawbacks, a capital gains preference policy does encourage savings. It also enhances one's capacity to invest more in one's human capital. Due to robust growth, real income is increasing; given this improvement in the fiscal situation, a tax reduction was feasible. From the macroeconomic angle, it is much less costly in terms of alternative budgetary revenue, to cut the upper tax bracket than the lower. From a political viewpoint, it was more difficult, because a lot got a little and a few got a lot. Inevitably, as a result of growing gross income and lower taxes, the propensity to save is rising, which, in the longer run, should finance additional investments and facilitate further growth.

\section{NOUVEAUX RICHES VERSUS NOUVEAUX PAUVRES}

Under central planning, there were poor and rich people. Determining the number of each depends on how they are counted. Whatever method is used, it is undeniable that the market transition has increased the number of both rich and poor. Because inequality has been increasing, so has the number of people at each end of the spectrum — the poor and the rich. Poverty and affluence can be measured in relative and absolute terms. Although some studies have focused upon the former group, we do not know much, for example, what proportion of the population should be counted as relatively, or even absolutely, rich. But, no doubt, they are there.

\footnotetext{
${ }^{33}$ About 91 percent of the population are in the lowest bracket. About 7 percent of taxpayers are in the middle bracket, and only 2 percent in the highest.
} 
The range of poverty in the transition countries-due to the decline in output and the long-lasting crisis - has increased significantly in the 1990s. As long as this decline in output is directly linked to the way the transition to a market is managed, growing poverty will be associated with transition. Only a few who were already poor prior to the postsocialist revolution, have been able to take their fate into their own hands in such manner that they were lucky enough to get out of poverty. And, unfortunately, the poor segment of society is growing. Although circumstances vary among countries, it is possible to group these countries into one of four categories, which range from "very high poverty" (a country where more than half the total population is counted as poor) to "low poverty" (where less than 5 percent is poor). ${ }^{34}$ (See Figure 4.)

An important issue related to this increase in poverty is the impact of increasing inequality on destitution. Several studies (UNICEF, 1995; Honkkila, 1997; Pomfret and Anderson, 1997; and Milanovic, 1998) have noticed that in some countries (e.g., Bulgaria, Estonia, Poland, Romania, and Uzbekistan), the rise in poverty is more a result of the decline in income equality than of falling income itself. This phenomenon should be

\footnotetext{
${ }^{34}$ Regarding the poverty classification for the transition countries, see Milanovic (1995). The poverty group consists of those with an annual income of less than US\$120 (on a PPP basis). Regarding the concept of poverty in China and Vietnam, see UNDP (1994).
} 


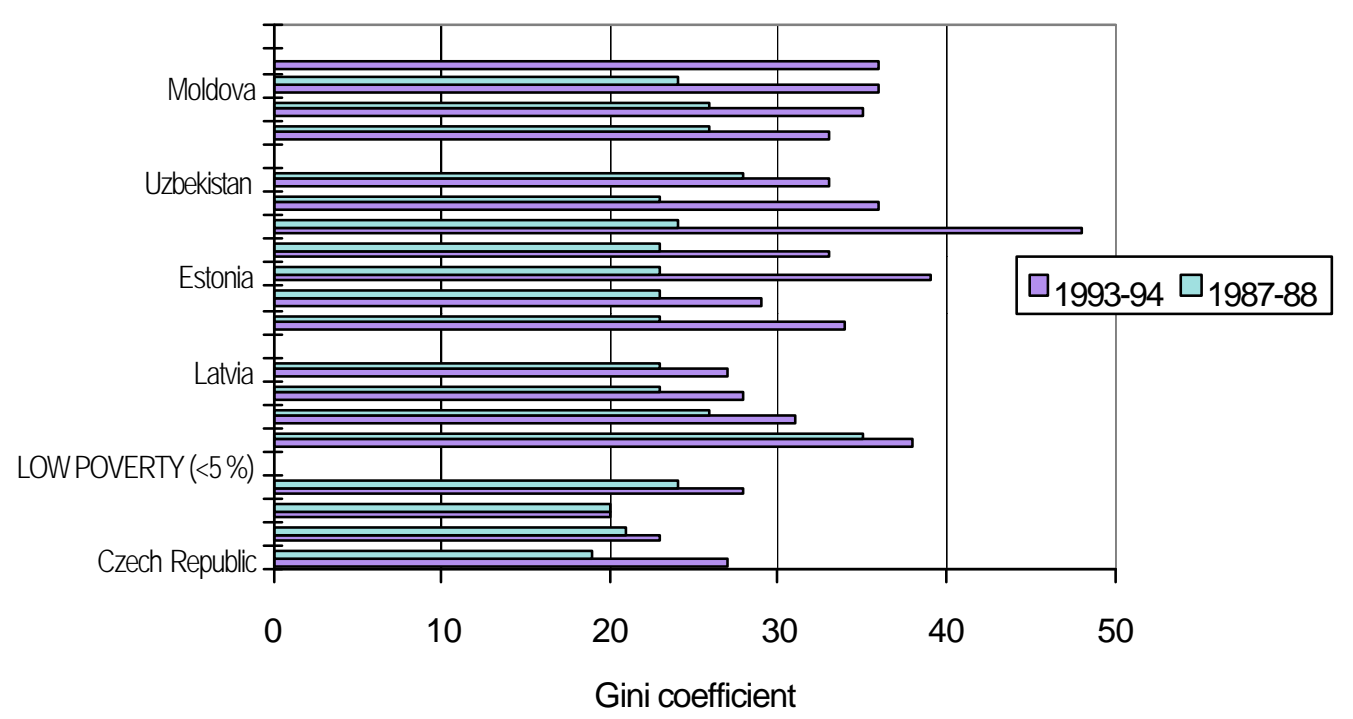


considered a very negative byproduct of transition (see Table 5). Although it has been simply impossible to contain poverty at the time of contraction of GDP - from 20 percent in Poland between mid-1989 and mid-1992 to as much as about 65 percent in Georgia, Moldova, and Tajikistan between 1990 and 1997— there are other significant factors that also contribute to the poverty.

First, the above-mentioned decline of production ignores the regional aspect of crises. Even when the economy is on the rise, the situation continues to deteriorate in the backward regions, so poverty grows.

Second, transition creates a labor market, so it brings unemployment, which is then worsened by the ongoing recession. The unemployed are provided with modest-if any-benefits. Many remain jobless for a long period and become more impoverished (Rutkowski, 1997). The transition countries were unprepared to tackle unemployment, especially a long-lasting one. Whereas in some advanced market economies, such as the United States, less than 5 percent of the unemployed remain jobless for more than one year, in a country like Poland, the figure is over 40 percent.

Third, most of the population, including the retired and those receiving relatively low pensions, had their savings eroded by rampant inflation and the lack of appropriate indexation mechanisms. In extreme cases, such as Russia's MMM schemes or Albania's 
Table 5: Increase in Poverty and GDP Decline During Transition, 1987-94

Poverty Relative to the Country
(21-27 percent of average income)
1989-90 1993-94 Increase

\author{
Poverty Relative to the World \\ (Income less than \$120 PPP)
}

1987-88 1993-94 Increase
1995 GDP

Index

(1989=100)

$$
\begin{gathered}
\text { (Percentage } \\
\text { change) }
\end{gathered}
$$

(Percentage

\begin{tabular}{|c|c|c|c|c|c|c|c|}
\hline Azerbaijan & 11.1 & 65.2 & 54.1 & $\ldots$ & $\ldots$ & $\ldots$ & 34 \\
\hline Belarus & $\ldots$ & $\ldots$ & $\ldots$ & 1 & 23 & 22 & 54 \\
\hline Bulgaria & 2.0 & 32.7 & 30.7 & 2 & 33 & 31 & 73 \\
\hline Czech Republic & 0.2 & 1.4 & 1.2 & 0 & $<1$ & $0-1$ & 87 \\
\hline Estonia & 1.0 & 27.0 & 26.0 & 1 & 40 & 39 & 66 \\
\hline Hungary & 1.1 & 4.0 & 2.9 & $<1$ & 3 & $2-3$ & 85 \\
\hline Kazakhstan & $\ldots$ & $\ldots$ & $\ldots$ & 5 & 50 & 45 & 46 \\
\hline Kyrgyz Republic & $\ldots$ & $\ldots$ & $\ldots$ & 12 & 84 & 72 & 42 \\
\hline Latvia & 1.3 & 33.5 & 32.2 & 1 & 25 & 24 & 54 \\
\hline Lithuania & 1.5 & 39.1 & 37.6 & 1 & 46 & 45 & 41 \\
\hline Moldova & 2.4 & 40.6 & 38.2 & 4 & 65 & 61 & 40 \\
\hline Poland & 5.8 & 10.9 & 5.1 & 6 & 19 & 13 & 99 \\
\hline Romania & 7.0 & 25.3 & 18.3 & 6 & 39 & 33 & 84 \\
\hline Russia & $\ldots$ & $\ldots$ & $\ldots$ & 2 & 45 & 43 & 54 \\
\hline Slovak Republic & 0.1 & 5.1 & 5.0 & 0 & $<1$ & $0-1$ & 86 \\
\hline Slovenia & 4.5 & 6.1 & 1.6 & 0 & $<1$ & $0-1$ & 93 \\
\hline Turkmenistan & $\ldots$ & $\ldots$ & $\ldots$ & 12 & 57 & 45 & 63 \\
\hline Ukraine & $\ldots$ & $\ldots$ & $\ldots$ & 2 & 41 & 39 & 40 \\
\hline Uzbekistan & $\ldots$ & $\ldots$ & $\ldots$ & 24 & 47 & 23 & 83 \\
\hline
\end{tabular}

change)

Sources: UNICEF (1995). Poverty lines: 21 percent of average income for the Czech Republic and Slovenia; 24 percent of average income for Estonia, Hungary, Latvia, Lithuania, Poland; and Slovak Republic; and 27 percent of average income for Azerbaijan, Moldova, and Romania (Milanovic (1996); EBRD (1996)).

disastrous, fraudulent pyramid schemes, weak and inefficient financial intermediaries as well as political negligence destroyed the savings of many households. 
Fourth, the ill-advised drive toward illusory fiscal prudence pushed some governments — and, again, Russia's case is the most spectacular-into postponing the payment of pensions and civil servants' salaries. The growing arrears, which are merely hidden budget deficit and disguised public debt, reflect the nominal equivalent of unpaid income, which further lower the standard of living.

Fifth, in the transition countries, the agricultural sector is still quite large. In Poland, which is already an OECD member, as much as 24 percent of the labor force is still engaged in farming. The rapid trade liberalization and inflow of imported food products from more competitive markets have ruined many small farms and left those farmers in poverty.

These five crucial factors led to the emergence of the nouveaux pauvres in the transition economies. On the one hand, the nouveaux pauvres are a consequence of the series of unavoidable events; on the other hand, they emerged because of policy mistakes. If it could not be better then it was before - under former centrally planned economy — at least it should not be as bad as it has turned out to be. The collapse in output and growing inequality have caused widening poverty, which, in turn, has caused a series of misfortunes: homeless people have appeared on the streets, crime rates are rising, economically motivated emigration has expanded, black markets have mushroomed, life expectancy has fallen (significantly in some countries), and mortality due to social stress has increased (Cornia, 1996b, and Paniccia, 1997).

Life expectancy in Russia and some other former Soviet Union countries (e.g., Latvia and Ukraine) has fallen by several years. Between 1989 and 1995, it dropped for men by a staggering six years. It is claimed (UNICEF, 1995; and Cornia, Honkkila, Paniccia, and Popov, 1996) that, due to this kind of demographic crisis, as many as two million people who were expected to live longer, have passed away. These authors claim that this excessive mortality has stemmed from the extraordinary hardships imposed by the way transition has been implemented and by the negative, accompanying factors, such as crime and violence. ${ }^{35}$

\footnotetext{
${ }^{35}$ In Russia, in 1996, deaths exceeded live births by 60 percent, due to the deterioration of the health standards. This deterioration was caused by poor diet, the breakdown of water quality control, the worsening of workplace safety, and the growing mortality due to violence, suicide, cardiovascular diseases, and stress. The maternal mortality continues to be 5-10 times higher in Russia than in Western Europe, and infant mortality 2-4 times higher. Deaths from tuberculosis in 1992-96 rose by as much as 90 percent.
} 
Poverty has widened in all transition economies, including those leading in both systemic change and growth, because of the time lag between recovery and growth and the improvement of the living standard for society's poorest. First, real output recovers, then employment grows, and finally the budget allows for better financing of the social needs of the poorest. Thus, an economy may be on the rise, but poverty will not decline for several years.

This sequence of events was seen, inter alia, in Poland, where until at least 1995-despite the resurgence of growth that began in the second half of 1992 - the scope of poverty did not decline. Unemployment rose until the summer of 1994, and salaries in many sectors did not grow until 1995. If the poor are counted as those living below the relative poverty line, defined as the equivalent of half of average monthly household expenditures - then the poor in Poland increased from 12 percent in 1993, to 13.5 percent in 1995, and to 14.0 percent in 1996 (GUS, 1996 and 1997a). Of course, this is a relative measure and does not mean that more people were driven at that time into absolute poverty; in fact, the opposite is true. The portion of the population that benefits from the ongoing economic expansion has been on the rise for a few years. This fact is confirmed by the households' own evaluation of the standard of living changes. Whereas more than 50 percent of Poland's households declared their economic position to be "bad" or "very bad" at the time of contraction (early 1990s), this figure fell to 32.5 percent in 1995 and to 30.3 percent in 1997 (GUS, 1997b).

Although it is true that the phenomenon of growing poverty has ended, it is also true that poverty still presents a tremendous challenge for the future. The next few years will determine what income distribution pattern will prevail in the transition economies. And not all countries will follow the same distribution model. It will not be that easy to correct all the mistakes that have been made thus far; since inequality has increased, it will be extremely difficult—maybe impossible to decrease it significantly in the coming years. The postsocialist genie has left the bottle and it will not be easy to put him back.

Transition has created a class of nouveaux riches as well. Most are well educated, hardworking people, and capable not only of taking care of their own wealth but of doing so by establishing new opportunities for other citizens to improve their standards of living. Of course, as frequently happens - again, because of weak institutional arrangements and market experience - there are the thieves, swindlers, and crooks. These and other pathologies must be combated. However, in most transition countries, the majority of the nouveaux riches are members of the new entrepreneurial class.

Some distribution mechanisms help the richfirst and only later help the rest of society. After a crisis and the following recession, it takes far longer for the real economy to recover output and profits that for the financial markets to soar. Thus, the living standard of the poor, lowered by the 
contraction, tends to last longer than that of the rich ${ }^{36}$ In extreme cases, while the real economy continued to shrink and therefore the poor became poorer, the financial markets were flourishing, so at least some of the nouveau riches became even richer.

Every market economy has its entrepreneurial class. They are keen to risk their income in the new ventures on which overall expansion depends. However, how a society distributes its income and wealth depends on historical processes and current policies, which have caused a much more unequal distribution in Latin American countries than in South East Asian. The way the postsocialist transformation has been managed so far and how it will deal with income distribution in the future will determine the distribution pattern. We can already see that some of them remind us of Latin American countries, others of South East Asian. Despite these similarities they create their own patterns with both, the nouveaux riches and the nouveaux pauvres at the same time. These are just two sides of the same coin.

\section{CONCLUSIONS}

Thus far, transition has brought mixed results. Although inequality has increased in all transition countries - from Albania to Estonia and from the Czech Republic to Mongolia—in some, has doubled (e.g., in Russia and Ukraine); in some, it has grown by only a couple of points (e.g., Poland and Slovenia); and in yet others, it has stabilized.

Nonetheless, not all changes reflecting income dispersion are going into the same direction. Inequality can be measured by different methods often with conflicting results. For instance, in Poland between 1994 and 1995, the Gini coefficient (in terms of wages) increased from 28.1 to 28.8; however, the decile ratio for wages was virtually unchanged, hovering around 3.4. This difference is

\footnotetext{
${ }^{36}$ Vice President of the World Bank, Mark Malloch Brown, in addressing the issue vis-à-vis the recent East Asian crisis, stressed that, "Although imbalance in distribution of income declined with growth, the pace of correcting this disparity has slowed down .. .Government-driven growth policies have focused on export industries, and no sufficient commitment was made for improving living standards." Quoted in Development News_Daily Summary, The World Bank, Washington D.C., March 12, 1998, after Asahi Shimbun, March 11, 1998, p. 12.
} 
significant, as people usually pay more attention to the latter, that is, to the ratio of rich to poor and how it has changed.

The biggest challenge for policymakers is how to deal with growing inequality and widening of poverty. This challenge is made more difficult by the interrelationship between the two as well as a severe, long-lasting recession. Hence, growing inequality is not only a political issue that will provoke tensions and conflicts, but one that creates an economic obstacle to durable growth.

One should not confuse the means and the ends of economic policy (Stiglitz, 1998). Income distribution and a socially acceptable distribution of wealth are just some of the important long-term policy targets. From this perspective, the goal of transition is not only systemic change, but, more important, greater efficiency, increased competitiveness, faster growth, and more sustainable development. Thus, transition is expected to improve the standard of living for all, or at least for the overwhelming majority. Otherwise, the exercise would not make much sense.

Considering the equity and equality issues in policymaking, one has to have a vision not a delusion. Although inequality must rise during transition, changes in inequity should be controlled and managed by sound policies. The scope and the pace of these changes cannot be left entirely to the just-released market forces.

In the real world, accomplishing these tasks and getting a political support for the implementation of necessary measures is quite difficult. Politics and policymaking are nothing more than the ability to tackle, time and again, conflicts of interest. This is especially true during a transition, when the policies must lead the shift from stabilization to growth, and consolidate the stabilization process into lasting stability.

When a policymaker trying to catch up with a more advanced world faces a trade-off between faster growth with higher inequality (but less poverty) and slower growth with lower inequality (but widening poverty), he can be happy because his choice is clear. Policy should facilitate sustainable development, and income policy should support that goal. Then, in the longer run, everyone's standard of living may improve. After the initial surge of inequality, and when the economy is on the rise, it may be even possible to reduce disparity without harming the ability to expand. This seems to be even more true for inequity. Therefore, the more the transition advances and the stronger the foundations for fast and durable growth, the weaker is the trade-off between equity and efficiency. 


\section{REFERENCES}

Alesina, Alberto, 1997, "The Political Economy of High and Low Growth,” paper prepared for Annual World Bank Conference on Development Ec onomics, Washington, April 30-May 1.

___ a and Roberto Perotti, 1996, "Income Distribution, Political Instability, and Investment," European Economic Review, Vol. 40 (June), pp. 1203-28.

Atkinson, Anthony B., and John Micklewright, 1992, Economic Transformation in Eastern Europe and the Distribution of Income (Cambridge, England: Cambridge University Press).

Atkinson, Anthony B., Lee Rainwater, and Timothy M. Smeeding, 1995, "Income Distribution in Advanced Economies: Evidence from the Luxembourg Income Study," Working Paper No. 120, Luxembourg Income Study (LIS), (New York: Syracuse University, Maxwell School of Citizenship and Public Affairs).

Blanchard, Olivier, 1997, The Economics of Post-Communist Transition (Oxford; New York: Clarendon Press).

Bruno, Michael, 1992, "Stabilization and Reform in Eastern Europe: A Preliminary Evaluation, IMF Working Paper 92/30 (Washington: International Monetary Fund).

Cornia, Giovanni Andrea, 1996a, "Transition and Income Distribution: Theory, Evidence and Initial Interpretation,” Research in Progress 1 (March), United Nations University, World Institute for Development Economics Research (Helsinki).

, 1996b, "Labour Market Shocks, Psychological Stress and the Transition's Mortality Crisis," Research in Progress 4 (October), United Nations University, World Institute for Development Economics Research (Helsinki).

___ , and Vladimir Popov, 1997, "Transition Strategies, Growth and Poverty (unpublished; Helsinki: United Nations University, World Institute for Development Economics Research).

Cornia, Giovanni Andrea, Juha Honkkila, Renato Paniccia, and Vladimir Popov, 1996, Long-Term Growth and Welfare in Transition Economies: The Impact of Demographic, Investment and Social Policy Changes," United Nations University /WIDER Working Paper No. 122 (Helsinki: United Nations University, World Institute for Development Economics Research).

Deininger, Klaus, and Lyn Squire, 1996, “A New Data Set Measuring Income Inequality,” World Bank Economic Review, Vol. 10 (September), pp. 565-91. 
Done, Kevin, 1997, “Investors Give Eastern Europe a Miss," Financial Times (London), April 15.

European Bank for Reconstruction and Development, 1996, Transition Report 1996 (London: EBRD).

Gomulka, Stanislaw, 1996, "Causes of Output Decline, Sources of Recovery and Prospects for Growth in Transition Economics (unpublished; London: London School of Economics).

Gregory, Paul R., 1997, “Transition Economies: Social Consequences of Transition,” paper prepared for United Nations Development Programme (unpublished; Houston: University of Houston).

Herer, Wiktor, and Wieslaw Sadowski, 1996, Szara gospodarka w Polsce-rozmiary, przyczyny, konsekwencje (The Gray Economy in Poland-Range, Sources, and Outcomes) (Warsaw: Zespol Badan Statystyczno-Ekonomicznych, GUS).

Honkkila, Juha, 1997, "Privatization, Asset Distribution and Equity in Transitional Economies," Working Paper No. 125 (Helsinki: United Nations University, World Institute for Development Economics Research).

International Monetary Fund, 1998, World Economic Outlook, May 1998: Financial CrisisCauses and Indicators, World Economic Financial Surveys (Washington).

Kolodko, Grzegorz. W, 1986, "Repressed Inflation and Inflationary Overhang Under Socialism," BEBR Faculty Working Paper No. 1228 (Urbana-Champaign, Ill.: University of Illinois).

___ , 1991, “Inflation Stabilization in Poland: A Year After,'Rivista di Politica Economica, Vol. 81 (June), pp. 289-330.

, 1992a, "Economics of Transition. From Shortageflation to Stagflation: The Case of Poland," in Preventing a New East-West Divide: The Economic and Social Imperatives of the Future Europe, edited by Armand Clesse and Rudolf Tokes (Baden-Baden: Nomos Verlagsgesellschaft), pp. 172-81. , 1992b, "From Output Collapse to Sustainable Growth in Transition Economies: The Fiscal Implications" (unpublished; Washington: International Monetary Fund). , 1996, Poland 2000: The New Economic Strategy (Warsaw: Poltext). 
Kolodko, Grzegorz W., and Walter W. McMahon, 1987, "Stagflation and Shortageflation: A Comparative Approach,” Kyklos, Vol. 40, No. 2, pp. 176-97.

Kolodko, Grzegorz W., and D. Mario Nuti, 1997, "The Polish Alternative: Old Myths, Hard Facts and New Strategies in the Successful Transformation of the Polish Economy," United Nations University/WIDER Research for Action 33, United Nations University, World Institute for Development Economics Research (Helsinki).

Kornai, János, 1980, Economics of Shortage (Amsterdam; New York: North-Holland Publishing Co.).

1993, "Transformational Recession: A General Phenomenon Examined Through the Example of Hungary's Development," Economie Appliqué, Vol. 46 (July), No. 2, pp.181-227.

Lavigne, Marie, 1995, The Economics of Transition: From Socialist Economy to Market Economy (New York: St. Martin's Press).

Milanovic, Branko, 1995, "Poverty, Inequality, and Social Policy in Transition Economies," Policy Research Working Paper 1995-11 (Washington: World Bank).

___ 1998, "Income, Inequality, and Poverty During the Transition from Planned to Market Economy," World Bank Regional and Sectoral Study 1998-2 (Washington).

Nuti, D. Mari, 1989, "Hidden and Repressed Inflation in Soviet-type Economies: Definitions, Measurements and Stabilization," in Models of Disequilibrium and Shortage in Centrally Planned Economies, edited by Christopher Davis and Wojciech Charemza. (London; New York: Chapman and Hall), pp. 101-46.

Organization for Economics Cooperation and Development, 1996, OECD Economic Surveys: Poland (Paris: OECD).

Paniccià, Renato, 1997, "Short- and Long-term Determinants of Cardiovascular Mortality: An Econometric Assessment of the Working Age Population in Russia, 1965-95," Research in Progress 14 (June), United Nations University, World Institute for Development Economics Research (Helsinki).

Poland, Central Statistical Office (Glowny Urzad Statystayczny (GUS), 1996, Ubostwo w swietle badan budzetow gospodarstw domowych (Poverty, Based on Household Budget Surveys) (Warsaw: GUS). 
___ 1997a, Monitoring warunkow zycia ludnosci (Monitoring the Population's Living Conditions), Septem 15 (Warsaw: GUS).

—__, 1997b, Wskazniki ubostwa (Poverty Iindicators, Based on Household Budget Surveys) (Warsaw: GUS).

Pomfret, Richard, and Kathryn H. Anderson, 1997, "Uzbekistan: Welfare Impact of Slow Transition," Working Paper No. 135 (Helsinki: United Nations University, World Institute for Development Economics Research).

Poznanski, Kazimierz, 1996, Poland's Protracted Transition: Institutional Change and Economic Growth, (Cambridge; New York: Cambridge University Press).

Rutkowski, Jan, 1997, 'Labor Markets, Welfare and Social Policy During Economic Transition in Poland," (unpublished; Warsaw: World Bank Field Office).

Stiglitz, Joseph E., 1998, "More Instruments and Broader Goals: Moving Toward the Post-Washington Consensus," WIDER Annual Lectures No. 2 (January), United Nations University, World Institute for Development Economics Research (Helsinki).

Tanzi, Vito, and Ke-young Chu, eds., 1998, Income Distribution and High-Quality Growth (Cambridge, Mass.; London: MIT Press).

United Nations Development Programme, 1994, Human Development Report 1994 (New York; Oxford: Oxford University Press).

___ 1996, Human Development Report 1996 (New York; Oxford: Oxford University Press).

United Nations Children's Fund International Child Development, 1995, "Poverty, Children and Policy: Responses for a Brighter Future," Regional Monitoring Report No. 3, Economies in Transition Studies (Florence: UNICEF Centre).

World Bank, 1995, “Understanding Poverty in Poland,” A World Bank Country Study (Washington).

___ 1996, World Development Report 1996: From Plan to Market. (New York: Oxford University Press for the World Bank).

___ 1997, World Development Report 1997: The State in a Changing World (New York: Oxford University Press for the World Bank). 
- 59 - 